\title{
Emergency Power and the Decline of Liberalism
}

\author{
Jules Lobel $\uparrow$
}

In 1987, The Miami Herald broke two major national news stories. The first captivated the public and mass media with lurid details of Democratic presidential candidate Gary Hart's sexual meanderings. The second revealed that Lieutenant Colonel Oliver North and the Federal Emergency Management Agency (FEMA) had drafted a contingency plan providing for the suspension of the Constitution, the imposition of martial law, and the appointment of military commanders to head state and local governments and to detain dissidents and Central American refugees in the event of a national crisis. ${ }^{1}$

The revelation that FEMA had drafted such an emergency plan attracted much less public interest than Gary Hart's sexual adventures. Major newspapers such as The Washington Post and The New York Times did not even run the FEMA story, and during the Iran-Contra hearings a question posed to Colonel North about the FEMA plan was scuttled when Senator Inouye referred it to a closed session. ${ }^{2}$

The FEMA plan may have failed to arouse attention because we have grown accustomed to the substantial and steady increase in the scope of executive emergency power during this century. This growth has taken numerous forms: the increased imposition of trade and travel restrictions, the deployment of military personnel alongside civilian law enforcement officials in waging the war on drugs, and the development of a parallel, secret government within the executive branch to confront certain foreign

$\dagger$ Associate Professor of Law, University of Pittsburgh School of Law. I would like to thank Harold Koh, Susan Koniak, Carlin Meyer, Todd May, Rhonda Wasserman, Welsh White and Barbara Wolvovitz for their valuable comments and suggestions, and Diane George and Elizabeth Schooley for their research assistance. Thanks also to LuAnn Driscoll and her staff at the word processing center at the University of Pittsburgh for their assistance in preparing the manuscript.

1. Reagan Advisors Ran Secret Government, Miami Herald, July 5, 1987, at 1, col 1. The plan, secretly obtained by The Herald, provided for an executive order that former President Reagan would sign but not make public until a crisis broke. Administration sources deny that the executive order was ever signed, although some congressional sources believe that President Reagan did sign an executive order in 1984 that revised national military mobilization measures to deal with civilians in a national crisis. Id. Attorney General William French Smith voiced his objections to the FEMA plan in a letter to Robert McFarlane dated August 2, 1984. Id. See also B. BradleE, Guts \& GloRY, The Rise and Fall of Oliver North 132-34 (1988) (discussing FEMA plan).

2. Miami Herald, July 15, 1987, at 11A, col. 1. Colonel North later denied drawing up or even knowing of such a plan in response to a question posed by Senator David Boren during the hearings. Id. 
threats. ${ }^{3}$ These assertions of emergency power have been largely tolerated because many Americans perceive them as worthy responses to an assault from abroad by communism, drugs, terrorism and refugees.

Executive reliance on emergency powers to respond to perceived foreign threats has presented a challenge to the maintenance of constitutional governance since the Republic's beginning." This Comment analyzes the historical expansion of the executive's emergency power to confront foreign dangers, from its philosophical roots to the demise of traditional limiting devices and the subsequent failure of reformist attempts to revive restraints. It argues that the undermining of liberal constitutional restraints on executive emergency power during the twentieth century has been caused less by legislative failure or by executive arrogance, than by the transformation of the eighteenth century world and the rise of American power in global affairs. In response to the changing international context, this Comment proposes new directions for limiting emergency powers.

\section{Constitutional Theories of Emergency Power and the Dichotomies of Liberal ThOUGHT}

A fundamental tension exists in any constitutional order between the basic premise of government constrained by law and the perceived need for unfettered, discretionary power to confront dire emergencies and crisis. That tension is expressed in various forms. Lincoln asked in 1861 whether a republic must "of necessity, be too strong for the liberties of its own people, or too weak to maintain its own existence?" The continuing debate over whether the perceived requirements of national security can be harmonized with traditional civil liberties and separation of powers, reflects Lincoln's concerns. Oliver Cromwell articulated the same conflict when he pithily stated before Parliament, "Necessity hath no law."

\section{A. Frameworks of Emergency Power: Absolutist, Relativist and Liberal}

Three frameworks have been proffered for resolving this tension between law and necessity. The absolutist perspective contends that the government has no emergency power to deal with crisis other than that spe-

3. See infra notes 178-196 and accompanying text.

4. Executive use of emergency powers to respond to foreign crisis threatens to undermine both constitutional separation of powers and individual liberties. As James Madison warned almost 200 years ago, "perhaps it is a universal truth that the loss of liberty at home is to be charged to provisions against danger, real or pretended, from abroad." A. Schlesinger, The Imperial. Presidency ix (1973) (quoting Letter from Madison to Jefferson, May 13, 1798); see also The Federalist No. 8, at 45 (A. Hamilton) (J. Cooke ed. 1961) ("Safety from external dangers is the most powerful director of national conduct. Even the most ardent love of liberty will, after time, give way to its dictates.").

5. 6 Messages \& Papers of THe Presidents 20 (J. Richardson ed. 1898) (President Lincoln's Message to Congress, July 4, 1861).

6. Radin, Martial Law \& the State of Siege, 30 CAlrf. L. REv. 634, 641 (1942) (quoting Oliver Cromwell). 
cifically provided by the Constitution. As the Supreme Court declared in Ex Parte Milligan, the Constitution works "equally in war and in peace," protecting "all classes of men, at all times, and under all circumstances." "The absolutist asks rhetorically, is it worth preserving the Constitution and country by trampling upon the basic liberty and freedoms upon which society is founded? ${ }^{8}$ The framers' failure to provide for any general emergency rule or martial law, ${ }^{9}$ apart from permitting the national government to call out the militia to suppress insurrections ${ }^{10}$ and suspend the writ of habeas corpus, ${ }^{11}$ is mustered as support for the absolutist outlook. ${ }^{12}$

This first perspective suppresses the tension between law and necessity by denying that such necessity exists in a time of crisis. ${ }^{13}$ Because as a

7. Ex Parte Milligan, 71 U.S. (4 Wall.) 2, 120-21 (1866). Milligan, an Indiana citizen, was tried and sentenced to death for disloyal activities during the Givil War by a military commission established by President Lincoln. After the Civil War ended, the Supreme Court unanimously held that President Lincoln had acted unconstitutionally in creating military commissions to try civilians where the civil courts were still functioning. The majority opinion written by Justice Davis went even further, stating that the rights contained in the Constitution with the exception of the writ of habeas corpus, could not be suspended by either the President or Congress. Id. at 125. Justice Davis wrote, "No doctrine, involving more pernicious consequences, was ever invented by the writ of man than that any of it's [the Constitution's] provisions can be suspended during any of the great exigencies of government." Id. at 120. The Court's absolutist decision has been severely criticized by some scholars and vicwed by others as a "political maneuver rather than as a constitutional homily." Roche, Executive Power \& Domestic Emergency: The Quest for Prerogative, 5 W. PoL. L.Q. 592, 600-01 (1952).

8. 71 U.S. at 126.

9. European and Latin American constitutions often do contain clauses providing for a general suspension of rights and liberties in periods of national emergency. See, e.g., A. PeasLeE, 4 Constrtutrons of Nations 907 (3d ed. 1970) (Mexican Constitution, Article 29); Clarke, Emergency Legislation, Fundamental Rights, and Article 28.3.3 of the Irish Constitution, 12 IRISH JUR. 217 (1977) (discussing Irish Constitution, Article 28); Glas, The New Spanish Constitution, Comments and Full Text, 7 Hastings Const. L.Q. 47, 61-62, n.n.70-71 (1979) (discussing the Spanish Constitution, Article 55); see also The European Convention for the Protection of Human Rights and Fundamental Freedoms, entered into force Sept. 3, 1953, art. 15, 213 U.N.T.S. 221 (Nov. 4, 1950); The International Covenant on Civil and Political Rights, entered into force March 23, 1976, art. 4, 21 U.N. GAOR Supp. (No. 16) at 49, U.N. Doc. A/6316, at 52 (1967); see generally Kairys, Exporting Freedom of Speech, in A Less Than Perfect Union, Alternative Perspectives on THE U.S. ConstTTUTION 387, 395 n.13 (J. Lobel ed. 1988) (collecting sources).

10. U.S. ConST. art. I, $\S 8$, cl. 15.

11. U.S. Const. art. $1, \S 9, \mathrm{cl} .2$.

12. The Court in Milligan viewed the absence of any provision in the Constitution providing for a general suspension of rights as indicating that the framers had limited the power of "suspension to one great right [habeas corpus] and left the rest to remain forever inviolable." 71 U.S. (4 Wall.) at 126.

13. There are two theoretical justifications for the absolutist view. The first, expressed by Judge Davis in Milligan, was that the Constitution grants the government sufficient power to preserve its existence without resorting to suspending rights or extraordinary emergency power. 71 U.S. (4 Wall.) at 121. See also Home Bldg. \& Loan Ass'n v. Blaisdell, 290 U.S. 398, 425-26 (1934) (emergency does not "create" or "increase" power; "Constitution was adopted in period of grave emergency" and its grants of power were determined in the light of emergency and are not altered by emergency). For example, the Court in Milligan denied that the safety of our nation ever required denying a citizen the right to a jury trial during wartime, unless an invasion actually closed the courts of a particular locality. 71 U.S. (4 Wall.) at 126-27. This rationale contains the seeds of a relativist perspective, in that it implicitly admits that if such a necessity did exist which required suspending rights and guarantees, the Constitution would grant the government such power.

The second absolutist justification-raising a basic question of values-argues that even if such necessity did exist, the preservation of the nation would not be worth the sacrifice of liberty. 71 U.S. 
practical matter such exigencies do arise, the absolutist view tends to be supplanted by a relativist perspective. In contrast to the absolutist's denial of the need for emergency power, the second, relativist position argues that the Constitution is a flexible document that permits the President to take whatever measures are necessary in crisis situations. As Alexander Hamilton noted, the constitutional power of the federal government to provide for national defense "ought to exist without limitation: because it is impossible to foresee or define the extent and variety of national exigencies, or the corresponding extent and variety of the means which may be necessary to satisfy them."14 Although Hamilton was discussing joint congressional and executive authority, modern Presidents have used a similar argument to justify their own unilateral emergency power. For example, President Franklin Roosevelt articulated the view that the President has the constitutional power to ignore statutory provisions when "necessary to avert a disaster which would interfere with the winning of the war."15

Both the relativist and absolutist views have an underlying philosophical unity, as both eviscerate the dichotomy between constitutional normalcy and extra-constitutional emergency. The first does so by denying the need for emergency power; the second does so by interpreting the Constitution to provide the Executive with the authority to use such extraordinary power.

Liberal constitutionalism sought throughout the eighteenth and early nineteenth centuries to resolve the tension between law and necessity through a third approach, one that preserved the dichotomy between ordinary and emergency power by positing a boundary line separating and protecting the normal constitutional order from the dark world of crisis government. Emergency and normal times were counterposed, resulting in distinct legal regimes. Normalcy permitted a governmental structure based on separation of powers, respect for civil liberties and the rule of law, while emergencies required strong executive rule, premised not on law and respect for civil liberties, but rather on discretion to take a wide range of actions to preserve the government. Even though necessity required such action, it was to be feared. As William Pitt noted in 1783, "Necessity is the plea for every infringement of human freedom. It is the argument of tyrants; it is the creed of slaves."18

(4 Wall.) at 126.

14. The Federalist No. 23, at 147 (A. Hamilton) (J. Cooke ed. 1961) (emphasis in original).

15. E. Corwin, The President, Office and Powers 250-51 (4th ed. 1957) (quoting Roosevelt's Speech to Congress, September 7, 1942). Roosevelt also sought to justify his power by invoking "Congressional acts," however Corwin and other scholars have viewed that justification as a "vague gesture" where "it is obvious that his principal reliance was, and could only have been, on his powers under the Constitution." Id.

16. Stavsky, The Doctrine of State Necessity in Pakistan, 16 CoRnell. INT'L L.J. 341 (1983) (quoting William Pitt). 
The attempt to address the tension between law and necessity by demarcating separate spheres of emergency versus non-emergency governance reflects a fundamental philosophical perspective of liberal constitutional thought. Liberal thought premises constitutional democracy upon the tension between polar opposites: between law and politics, public and private, state and civil society, universal and particular, reason and desire, self and other. ${ }^{17}$ These distinctions attempt to separate the areas of our existence that can be governed by universal, collectively-derived and reasoned rules, from those areas that we want to preserve for particularized decisionmaking. ${ }^{18}$ Liberalism in this sense is not simply a specific political position, but a world view that seeks to resolve societal tensions by creating a legally significant dividing line between the two poles of the tension. ${ }^{19}$ The constitutional restraints on emergency powers explicitly manifest a series of dualities in accordance with the liberal paradigm: crisis and normalcy, war and peace, constitutional and unconstitutional action.

Two mechanisms serve to demarcate true emergencies from nonemergency situations in the classical liberal paradigm. The first is the implicit assumption that emergency rule is aberrational. ${ }^{20}$ Only the gravest of national emergencies warrant drastic action. The second mechanism equates the emergency/non-emergency dichotomy with the distinction between constitutional and unconstitutional action. The Constitution did not grant the executive any general, inherent, constitutional emergency authority. Rather, eighteenth century leaders and philosophers believed that the executive should be required knowingly to act illegally or unconstitutionally when utilizing emergency power. For these thinkers, emergency power was an unconstitutional exercise of power by the executive. Offi-

17. K. Mannheim, Ideology \& Utopia 25-26 (1966) (split between individual and group); K. Marx, On the Jewish Question in Writings of THE Young MARX ON PhILOSOPHy and Society 216 (L. Easton \& K. Guddat eds. \& trans. 1967) (discussing state/civil society distinction); R. UNGER, KNOWLEDGE \& POLITICS 44-45 (1975) (setting forth series of dichotomies that run through liberal psychology); Frug, The City as a Legal Concept, 93 HARv. L. Rev. 1059, 1075 (1980) (liberalism sees world as series of complex dualities); Kahn, Reason $\&$ Will in the Origins of American Constitutionalism, 98 YALE L.J. 429, 459-61 (1988) (dichotomy of reason and passion); Kennedy, The Stages of the Decline of the Public/Private Distinction, 130 U. PA. L. Rev. 1349 (1982) (liberal way of thinking involves set of distinctions such as state/society, individual/group, law/policy, public/ private); Kennedy, The Structure of Blackstone's Commentaries, 28 Buffalo L. REv. 205, 217 (1979) (defining liberalism as splitting universe into two radically opposed imaginary entities).

18. See, e.g., Seidman, Public Principle \& Private Choice: The Uneasy Case for a Boundary Maintenance Theory of Constitutional Law, 96 YALE L.J. 1006, 1019-23 (1987) (describing tension between universalism and particularism). Various Marxist writers have traced this tension back to a duality in the nature of commodities in Capitalist society which have both a particular use and a universal monetary, or exchange, value. E. PAshukanis, LAw \& MarXism, A General Theory (1929).

19. Frug, supra note 17, at 1075. As Professor Tribe has noted: "The rule of law in the liberal state is to a significant degree predicated on possessively individualist assumptions which generate pressure for the formal conception of fixed rules as solutions to the tension between order and freedom." Tribe, Structural Due Process, 10 HARv. C.R.-C.L. L. REv. 269, 311 (1975) (citing D. Kennedy, Legal Formality, 2 J. LEgaL STUd. 351 (1973)).

20. Miller, Constitutional Law: Crisis Government Becomes the Norm, 39 Oню St. L.J. 736, 738 (1978) (Constitution predicated on assumption that crisis is aberrational). 
cials risked censure and even impeachment for engaging in activities justified solely by the perception of an emergency context. Courts could impose personal liability on those executive officials who undertook unconstitutional actions, even when such officials acted pursuant to good faith motivations to defuse a crisis. Subsequent to a court's declaration of the unlawfulness of an exercise of emergency power, however, Congress could decide to indemnify the official if it believed the official's actions really were justified by extreme necessity. This system allowed the executive to act without creating inherent emergency power under the Constitution. Furthermore, this identification of crisis activity as unlawful and subject to review reinforced the primary assumption that emergencies were not the norm.

Classical liberal theory thus divides executive action into two spheres: normal constitutional conduct, inhabited by law, universal rules and reasoned discourse; and a realm where universal rules are inadequate to meet the particular emergency situation and where law must be replaced by discretion and politics. The recognition of emergency power evidences an awareness that those universal rules might not suffice in a particular emergency situation. The classical liberal answer is not to weaken the universal rule by providing exceptions for special emergency situations, because creating either a plethora of legal exceptions or inherent executive constitutional power to meet every conceivable emergency would undermine the distinction between emergency and non-emergency actions. Rather, liberalism seeks to separate emergency rule from the normal constitutional order, thereby preserving the Constitution in its pristine form while providing the executive with the power, but not legal authority, to act in an emergency.

The emergency situation that particularly concerned the framers was that of war, the "true nurse of executive aggrandizement."21 Madison's characterization of war reflects the need for a dichotomy between war-the most extreme emergency situation-and peacetime constitutional order: "[I]n war . . . [t]he strongest passions and most dangerous weaknesses of the human breast; ambition, avarice, vanity," encircle the "executive brow." 22 The framers assumed that peace would be the normal state for the new republic and war, like other emergency power situations, would be aberrational. ${ }^{28}$ The constitutional requirement that Congress

21. J. Madison, Helvidius No. 4, in 6 Writings of James Madison 174 (G. Hunt ed. 1906). 22. Id.

23. See War Powers Legislation Hearings on S. 731, S.J. Res. 18, and S.J. Res. 59 Before the Senate Comm. on Foreign Relations, 92d Cong., 1st Sess. 86 (1971) (testimony of Richard Morris, Professor of History, Columbia University). Liberal philosophers of the late eighteenth century assumed that "peace and moderation are the spirit of a republic." M. HoWARD, WAR AND THE LiBERAL CONSCIENCE 25 (1978) (quoting Montesquieu); see also id. at 25-27 (views of Kant, Rousseau, Condorcet, and Paine that Republic would tend naturally to peace). These philosophical perspectives were buttressed by the practical political position that the United States would avoid European wars and advance its commercial interests. See, e.g., Letter from E. Randolph to J. Monroe, June 1, 1795, 
authorize the use of United States armed force against another nation was designed to ensure that war would truly be an extraordinary measure, ${ }^{24}$ and thus demarcate the executive's emergency war power from the peacetime order. The Constitution granted the President only the very limited emergency power to repel an attack. ${ }^{25}$ By carefully delineating between the offensive and defensive use of force, the Constitution created a boundary that executive power could not cross. ${ }^{26}$ Outside of these two scenarios-congressional authorization and repelling an attack-the Executive's exercise of emergency power to use armed force required the President to act unconstitutionally. ${ }^{27}$

in 1 american State Papers, Foreign Relations 706 (W. Lawrie and M. Clark eds. 1883) (assuming country would avoid war); 4 P. JESSUP, NeUTRALITY, IT's History, ECONOMIES AND LAW: TODAY AND TOMORROW 12 (1934) (quoting Jefferson's statement, "I hope the new world will fatten on the follies of the old").

24. James Wilson, a key figure at the Constitutional Convention, noted that the vesting of the power to declare war in Congress was designed to ensure that only a strong interest would involve us in war. $2 \mathrm{~J}$. Elliot, The Debates in the Several State Conventions on the Adoption of the Federal Constitution 528 (1937). See also 4 Id. at 197 (remarks of James Iredell); $1 \mathrm{~J}$. KENT, COMMENTARIES 55 (1826) (power of declaring war vested in legislature because "presumption is, that nothing short of a strong case" would move Congress to declare war).

25. There has been, of course, intense and voluminous scholarly debate on whether the Constitution did intend carefully to limit executive power to that of repelling armed attack. Compare infra note 26 (citing sources interpreting executive's power as limited) with Rogers, Congress, the President \& the War Powers, 59 GaLIF. L. REv. 1194 (1971) (urging broader executive authority than just repelling attacks); Rostow, Great Cases Make Bad Law, 50 TEx. L. REv. 833 (1972) (asserting that executive has power unilaterally to use armed force); Rostow, Once More Unto the Breach: The War Powers Resolution Revisited, 21 VAL. U.L. REv. 1 (1986) (same). Abraham Sofaer and others have explored the practice of early presidents, concluding that in practice, the line between executive and legislative war-making authority was often blurred. A. SofAER, WAR, ForeIGN AFFaIRS AND CoNstrrutronal Power (1976); see also Emerson, War Powers Legislation, 74 W. VA. L. Rev. 53 (1971) (canvassing historical record for instances of executive use of force). Sofaer recognizes, however, that the early presidents did not claim any inherent authority to initiate military actions. A. SOFAER, supra, at 378 . This Comment will not attempt to reargue in detail the debate that has been substantially elaborated elsewhere.

26. For a discussion of the allocation to the President of the narrow power to defend the country from attack, see S. ReP. No. 220, 93rd Cong., 1st Sess. 10-14 (1973); E. KeYNES, UNDECLARED War, Twilight Zone of Constituttonal Power (1982); F. Wormuth \& E. Firmage, To Chain the Dog of War, the War Power of Congress in History and Law (1986); Berger, War Making by the President, 121 U. PA. L. Rev. 29, $42-44$ (1972); Friedman, Waging War Against Checks and Balances-The Claim of an Unlimited Presidential War Power, 57 ST. JoHN's L. Rev. 213, 220-23 (1983); Lobel, Covert War \& Congressional Authority: Hidden War \& Forgotten Power, 134 U. PA. L. REv. 1035, 1059-60, 1077-78 (1986); Lofgren, War Making Under the Constitution: The Original Understanding, 81 YalE L.J. 672, 676 (1972); Van Alstyne, A Requiem for Vietnam, 121 U. PA. L. REv. 1, 7-8 (1972).

27. At first glance, the mechanism used to draw a line between war and peace appears different than that used to demarcate emergency from non-emergency power in that the war/peace distinction allows the Executive some constitutional emergency power to repel an armed attack. Yet, a closer look at the emergency/non-emergency dichotomy reveals an analogous power. For example, even the absolutist court in Milligan recognized that when the civil courts were not functioning, the Executive had constitutional emergency power to try civilians by military courts. Ex Parte Milligan, 71 U.S. (4 Wall.) 2, 126-27; see supra note 13. Similarly, the Court in Mitchell v. Harmony recognized that when American property was about to be seized by the enemy during war, executive officials had constitutional authorization to seize it themselves. 54 U.S. (13 How.) 128, 134 (1851); see infra note 46 and accompanying text. In war or emergency, the Executive has constitutional authority only when the emergency is physically forced upon the country and there is no option but to respond (i.e., the courts are closed, the enemy is attacking). Responding is not really a discretionary act when the courts are closed or the enemy is attacking, it is a physical necessity. Short of that situation, there are other 
Elements of all three frameworks of emergency power-what I have termed the absolutist, relativist and liberal-have been present throughout our constitutional history. Yet in the early years of our Nation's existence, the liberal theory was dominant. Only in the twentieth century has the relativist perspective come to dominate the government's perspective on emergency power.

\section{B. The Origin and Early Operation of the Liberal Paradigm of Emer- gency Power}

The roots of the liberal tradition of emergency power can be traced to John Locke. Locke relied on the English doctrine of prerogative to address unforeseen "Necessities"- where the "Law-making" power was either "[t]oo numerous" or "too slow, for the dispatch requisite to Execution." In such cases, "it's fit that the laws themselves . . . give way to the executive Power, or rather to this Fundamental Law of Nature and Government . . . that all the Members of the Society are to be preserved." 28 The executive's prerogative was the power to act "according to discretion, for the public good, without the prescription of the law, and sometimes even against it." ${ }^{29}$ An emergency permitted the disregard of even the "direct letter of the law." ${ }^{30}$ The key attribute of Locke's portrayal of executive prerogative was the extra-legal power dictated by necessity.

The dominant American constitutional theory of emergency power was similar to that espoused by Locke. President Thomas Jefferson adhered to the view that the Constitution carefully limited executive emergency power and therefore openly acknowledged that certain emergency actions were unlawful, requiring public ratification by Congress. ${ }^{31} \mathrm{He}$ feared that the Louisiana Purchase was unconstitutional, but believed that the emergency required the legislature to act and "throw themselves on their country for doing ... unauthorized, what we know [the people] would have done for themselves had they been in a situation to do it."32 In 1806, during a congressional recess, a British frigate attacked a United States ship. Jefferson provided the funds for munitions needed to defend American positions, even though such action exceeded his authority under the

potential emergencies where the Executive is not constitutionally empowered to act, but might act unconstitutionally if she believes the threat is grave enough. Lobel, supra note 26, at 1059-60, 1077-78 (1986).

28. J. Locke, Two Treatises of Government § 159-60, at 392-93 (P. Laslett ed. 1970).

29. Id.

30. Id. § 164, at 395. Other liberal philosophers echoed Locke's position. Rousseau recognized the need for an extra-legal "supreme ruler who shall silence all the laws," "if the peril is of such a kind that the paraphernalia of the laws are an obstacle to their preservation." J. SMIIH \& C. CorTER, Powers of The President During Crisis 6 (1960). Similarly, John Stuart Mill defended representative democracy but refused to condemn a "temporary dictatorship" which would assume absolute power in cases of extreme necessity. Id. at 7.

31. A. SChlesinger, supra note 4 , at 23-25.

32. Id. at 24. 
appropriation laws. ${ }^{33} \mathrm{He}$ then made a full disclosure to Congress, admitting that, because of the need for strong, swift action, he had acted without a "previous and special sanction by law," and requested congressional approval. ${ }^{34}$ In 1807, upon confronting the Burr conspiracy, Jefferson again argued that "On great occasions . . . every good officer must be ready to risk himself in going beyond the strict line of the law, when the public preservation requires it; his motives will be a justification." 35

After he left the presidency, Jefferson was asked to comment on whether there are "not periods when, in free governments, it is necessary for officers in responsible stations to exercise an authority beyond the law. . .."38 Jefferson responded:

A strict observance of the written laws is doubtless one of the high duties of a good citizen, but it is not the highest. The laws of necessity, of self-preservation, of saving our country when in danger, are of higher obligation. To lose our country by a scrupulous adherence to written law, would be to lose the law itself, with life, liberty, property and all those who are enjoying them with us; thus absurdly sacrificing the end to the means.

The officer who is called to act on this superior ground, does indeed risk himself on the justice of the controlling powers of the Constitution, and his station makes it his duty to incur that risk. . . . The line of discrimination between cases may be difficult; but the good officer is bound to draw it at his own peril, and throw himself on the justice of his country and the rectitude of his motives. ${ }^{37}$

\section{Other early leaders took similar positions. ${ }^{38}$ Representative White of}

33. Wilmerding, The President and the Law, 67 PoL. Scr. Q. 321, 323 (1952).

34. 1 Compilation of the Messages and Papers of THE PREsidents 428 (J. Richardson ed. 1898). Congress eventually approved Jefferson's conduct, although it recognized that the President had acted illegally. Jefferson did not attempt to legitimize his orders under the Constitution, he justified the purchase on the ground of emergency. Sofaer, The Presidency, War, and Foreign Affairs: Practice Under the Framers, 40 LAw \& ConTEMP. Pross. 12, 221 (1976). Wilmerding, supra note 33 , at 322. Sofaer notes that Jefferson, rather than reshape Republican theory to provide for constitutional authority, resorted to the Lockean theory of extra-legal emergency power. A. SOFAER, supra note 25, at 226-77. Sofaer, however, argues that Jefferson's theory provided the President with more power than the relativistic Hamiltonian perspective. Id. at 227.

35. A. SChlesinger, supra note 4, at 24 . The Burr conspiracy is seen by some, however, as a dubious use of emergency power. The judicial system later acquitted Burr of treason. Id. at 25 .

36. Wilmerding, supra note 33, at 328. (quoting Letter from John B. Colvin to Jefferson, Sept. $14,1810)$.

37. Letter from Jefferson to Colvin, Sept. 20,1810 , in 11 The Works of Thomas JefFerson 146, 148-49 (P. Ford ed. 1905).

38. Professor Lucius Wilmerding, who undertook a careful study of the early President's utilization of emergency powers, concluded that the early leaders of the Republic generally supported the theory expressed by Jefferson and White. Wilmerding, supra note 33; see also Dennison, Martial Law: The Development of a Theory of Emergency Powers, 1776-1861, 18 AM. J. LEGAL HIST. 52, 58 (1974) (during debates over Burr Conspiracy, all agreed that "necessity could require a departure from regular processes, but that the constitution disallowed a deliberate substitution of another legal system"). 
Virginia explained to the First Congress that Virginia's governor had exceeded his lawful authority in obtaining supplies for the army during the Revolutionary War. Although the Governor's actions were admittedly illegal, they benefitted the country in time of dire necessity, and therefore he was afterward indemnified by the legislature. According to White, this procedure "corresponds with the practice under every limited government."39

General Andrew Jackson's actions in the aftermath of his victory over the British at New Orleans in 1815 further illustrate the Jeffersonian theory of emergency power. When Jackson's activities under martial law were challenged in a court action, his main justification relied on Jefferson's view that necessity " 'may in some cases . . . justify a departure from the constitution." "40 President Madison, relieved that Jackson based his defense on necessity, observed that even though a suspension of liberties "may be justified by the law of necessity," the commander "cannot resort to the established law of the land, for the means of vindication."1 The federal court held Jackson's actions to be unlawful, and it fined him $\$ 1,000$. Almost 30 years later, Congress enacted legislation to repay Jackson the principal and interest on the fine. ${ }^{42}$

As Jackson recognized, executive officials who departed from legal norms in times of war or emergency could be liable for damages to individuals who suffered injury due to their actions. Courts could sanction executive officials who violated the law irrespective of the necessity for the actions. In Little v. Barreme, a unanimous Supreme Court upheld the imposition of individual liability on a naval commander for violation of a congressional statute, even though he had acted pursuant to a Presidential Order. ${ }^{43}$ Congress then decided to indemnify the naval officer, because his unlawful actions had aided the nation during wartime.4

Similarly, in The Apollon, the Court assessed damages against an exec-

39. Wilmerding, supra note 33, at 323 (quoting Representative White).

40. Sofaer, Emergency Power and The Hero of New Orleans, 2 Gardozo L. Rev. 233, 245-46 (1981). Jackson arrested a Louisiana legislator named Louaillier, believing such action to be necessary to prevent a mutiny in his army. When the local Federal judge issued a writ of habeas corpus, he too was arrested. Louaillier was acquitted by a military court, yet Jackson refused to release him, contending that martial law authorized him to disregard the court's judgment.

After the peace treaty with Britain was ratified, Jackson revoked martial law and released his prisoners. Contempt proceedings against Jackson were commenced before the very judge he had previously arrested. Jackson justified his conduct with two somewhat contradictory legal arguments. The first was that his actions were a constitutional exercise of power pursuant to martial law, an argument apparently propounded by a legal aide named Abner Duncan. Dennison, supra note 38, at 61-64. His main defense was that his actions pursuant to martial law were justified by "necessity," since, as Jackson's other legal aide Edward Livingston informed him, "the general proclaims it [martial law] at his own risk, and under his responsibility, not only to the government, but to individuals, because it is a measure unknown to the Constitution and laws of the United States." Id. at 61.

41. Sofaer, supra note 40 , at 249. Madison erroneously claimed that Jackson based his defense solely on necessity. Id.

42. Id. at $248-51$.

43. 6 U.S. (2 Cranch) 170 (1804).

44. Wilmerding, supra note 33 , at 324 n.6. 
utive official for the seizure of a ship and cargo, even though the official had been motivated by perceived necessity. Justice Story wrote for a unanimous court:

It may be fit and proper for the government, in the exercise of the high discretion confided to the executive, for great public purposes, to act on a sudden emergency, or to prevent an irreparable mischief, by summary measures, which are not found in the text of the laws. Such measures are properly matters of state, and if the responsibility is taken, under justifiable circumstances, the legislature will doubtless apply a proper indemnity. But this Court can only look to the questions, whether the laws have been violated; and if they were, justice demands, that the injured party should receive a suitable redress. ${ }^{45}$

Alternatively, the courts enforced the boundary line between executive emergency power and the constitutional order by adjudicating whether an emergency did exist. In Mitchell v. Harmony, for instance, the Supreme Court upheld a damage award against a commander for the improper seizure of property during the Mexican War, ruling that the question of whether an emergency had been present was for the jury to determine. ${ }^{46}$ While the Mitchell Court did permit a very narrow area of lawful executive emergency power to seize property during wartime, its main emphasis was on limiting that power by defining emergency extremely narrowly. ${ }^{47}$

These cases illustrate that review by the courts of executive responses to foreign threats played an important role in the maintenance of a boundary between constitutional order and emergency power. In none of these cases did the Court decide either that the dispute was non-justiciable or that broad, inherent, executive constitutional powers over war and foreign affairs authorized the acts. ${ }^{48}$

\footnotetext{
45. 22 U.S. (9 Wheat) $362,366-67$ (1824).

46. 54 U.S. (13 How.) 128, 133-35 (1851).

47. The standard utilized by the Court was that the danger must be "immediate and impending," "such as will not admit of delay." 54 U.S. at 134. That the officer honestly believed such emergency to exist and took the property to promote the public service was deemed insufficient if there were no reasonable grounds for the officer's belief that the peril was "immediate and menacing." 54 U.S. at 135. This standard for emergency power is similar to the narrow exception given the President to repel an armed attack-in both cases, action is necessary before the legislative or civil authority can

48. For an excellent discussion of Little v. Barreme, see Glennon, Two Views of Presidential Foreign Affairs Power: Little v. Barreme or Curtis Wright, 13 YALE J. INT'L L. 5 (1988). In Martin v. Mott, 24 U.S. (12 Wheat.) 10 (1827), the Supreme Court did refuse to decide whether an emergency existed justifying the President's calling the militia into actual service, thus illustrating that the Court was, at times, reluctant to adjudicate executive use of emergency power. In Martin, however, the issue was not the executive's independent power: Congress had clearly authorized the President's actions, and the issue was whether a soidier could refuse an executive order because he did not believe an emergency existed. As Professor Christopher May has written in discussing this early period, "Where the executive had proceeded on its own, the judiciary displayed a remarkable willingness to analyze the relationship between its conduct and the war emergency." C. MAY, IN THE NAME OF War, Judicial Review and the War Powers Since 1918, at 18 (1989).
} act. 
These early examples illustrate an attempt to resolve the conflict between constitutional governance and emergency power by isolating and bounding emergency power within narrowly confined, non-constitutional limits. ${ }^{49}$ The following elements were required of official emergency action in violation of the law within this liberal tradition: the presence of an extreme emergency threatening the nation, the termination of the unlawful conduct when the emergency ended, the frank acknowledgment by the official that he had acted unlawfully, review of the unlawful conduct by Congress or the courts, and the appropriate implementation of legal remedies and congressional indemnification.

Reliance on the liberal paradigm's premise, that a limitation upon executive emergency power results from a requirement that the executive act unconstitutionally, contains certain dangers. The liberal system creates a precedent for permitting the President to engage in unlawful conduct and to disrespect the Constitution. Most early leaders of the Republic, however, generally believed that the problems associated with creating a constitutional basis for the exercise of emergency power outweighed the dangers of allowing the President to act extra-constitutionally and unlawfully in extreme crisis situations. ${ }^{50} \mathrm{~A}$ requirement that the President act unconstitutionally ensures that Congress will have to decide whether or not to ratify his actions. Moreover, in the liberal paradigm, activity beyond constitutional limits is likely to be both temporary and unusual because of the American public's respect for the Constitution and suspicion of any actions which openly contravene it.

Vague constitutional requirements that the President act in the "national interest" are not constraints on emergency power in the liberal tradition. The Jeffersonian position implicitly argues that reading the Constitution to provide for broad emergency power in the executive is unwise,

49. President Lincoln's justification for his actions taken during the Civil War contained aspects of both the relativist and liberal perspectives. Reporting to Congress in 1861, he argued that measures taken to crush the rebellion "whether strictly legal or not, were ventured upon under what appeared to be a popular demand, and a public necessity, trusting then, as now, that Congress would readily ratify them." 6 Messages AND Papers of THE PResidents 20, 24 (J. Richardson ed. 1898) (emphasis added). This view suggested that Lincoln believed that he could take unlawful measures dictated by public necessity-a position consistent with that articulated by Madison and Jefferson. See Hurtgen, The Case for Presidential Prerogative, 17 Toledo L. REv. 59, 68 (1975) (interpreting 1861 message as public concession by Lincoln that his measures were partly unconstitutional). In 1864, Lincoln articulated a more relativist perspective that "measures, otherwise unconstitutional, might become lawful, by becoming indispensable to the preservation of the constitution, through the preservation of the nation." Letter from Abraham Lincoln to A.G. Hodges (April 4, 1864), reprinted in 10 CoMplete WORKS OF ABrahaM Lincoln 65-66 (J. Nicolay \& J. Harp eds. 1894).

50. Justice Jackson's dissent in Korematsu sounded the same theme. Korematsu v. United States, 323 U.S. 214, 244, 246 (1944) (Jackson, J., dissenting). Jackson recognized that military necessity might often require that "the paramount consideration be that [the government's] measures be successful rather than legal. But if we cannot confine military expedients by the Constitution, neither would I distort the Constitution to approve all that the military may deem expedient. . . . A military commander may overstep the bound of constitutionality and it is an incident. But if we review and approve, that passing incident becomes the doctrine of the Constitution. There it has a generative power of its own, and all that it creates will be in its own image." Id. at 244, 246 (Jackson, J., dissenting). 
because it would inevitably lead to vast assertions of executive power unjustified by actual emergencies. As Justice Jackson more recently noted, "[E]mergency powers ... tend to kindle emergencies." In sum, in the eighteenth and early nineteenth centuries, a requirement that executive officials act unconstitutionally to respond to dire emergencies was designed to ensure that presidents acted only where the weightiest national security concerns were present.

\section{The Transformation of the Dominant Theory of EMERGENCY POWER}

Eighteenth and nineteenth century America's resolution of the tension between normalcy and necessity by means of two-dimensional line drawing between lawful and extra-constitutional exercises of executive power was made possible and conditioned by America's place and role in the world. The possibility of executive resort to unconstitutional conduct during a crisis was minimized because a militarily weak and geographically isolated America largely refrained from actively pursuing confrontations with threatening, foreign elements. Early United States foreign policy was designed to avoid, as far as possible, political entanglement in European affairs. ${ }^{\text {.2 }}$ Washington's farewell address, Jefferson's "fear of Europe's contamination," and Benjamin Rush's advice that "America should be greatly happy by erecting a barrier against the corruption in morals, government and religion which now pervade all the nations of Europe," ${ }^{253}$ all reflected the widespread conviction among the Founding Fathers that America was unique and would have to separate itself to avoid the wars and contamination of the Old World. ${ }^{54}$ America could believe that it was exceptional, "above" the nations of the world, without having constant crises in reaction to threatening foreign elements, because the nation was largely living apart from the other nations of the world. ${ }^{.5}$ This isolationism in turn encouraged the American public and political leadership to

51. Youngstown Sheet \& Tube Co. v. Sawyer, 343 U.S. 579, 650 (1952) (Jackson, J., concurring).

52. Jefferson in his Third Annual Message in 1803 noted, "Separated by a wide ocean from the nations of Europe, and from the political interests which entangle them, together with products and wants which render our commerce and friendship useful to them and theirs to us, it cannot be in the interest if any to assail us, nor ours to distrust them." 3 F. Wharton, A Digest of INTERNATIONAL LAW OF THE UNITED STATES 514 (2d ed. 1887). Washington's farewell address urged that "the great rule of conduct in regard to foreign nations, is in extending our commercial relations, to have as little political connection as possible." 1 AMERican State PAPERS, supra note 23, at 37.

53. H. Commager, The Defeat of America 25 (1968).

54. Thomas Paine wrote of America as creating "a new method of thinking," while the young Noah Webster spoke of America as an "independent empire" which "ought to assume a national character." Id. at 31.

55. Id. at 23; L. Hartz, The Liberal Tradition in America 37 (1955). One scholar has noted that Americans failed to develop an expansive view of martial law, "most probably because they never faced severe challenges to established authority between 1787 and 1840 ." Dennison, supra note 38 , at 66 . 
take a narrow view of executive emergency and war powers and to seek to delimit strictly such authority.

In addition, isolationism and separatism ${ }^{56}$ were psychologically and philosophically conducive to the development of a constitutional vision that emphasized the dichotomy between emergency and non-emergency power. ${ }^{57} \mathrm{~A}$ foreign policy that emphasized the Atlantic Ocean as a means to cordon off America from danger abroad directly corresponds with a constitutional policy that seeks to isolate and separate dangers of emergency rule from normal constitutional rule. "Erecting a barrier against the corruption" of Europe is psychologically connected to erecting constitutional barriers to prevent the corruption of the body politic by means of war or emergency power. ${ }^{58}$ The sense of "us versus them" fostered by separation and isolation led us to view the world in dualities, rendering it easier to view our own Constitution dualistically.

In the twentieth century, however, the United States turned towards globalism and international power. The rise of the American empire began to muddy the boundaries dividing emergency and normal legal orders, war and peace, totalitarianism and the republic. With the extrusion of American power abroad, the limitations on presidential power, so carefully guarded by the early leaders of the republic, began to erode.

The transformation of the executive's emergency powers began during the two decades preceding World War I. The United States' assertive exercise of military power abroad, the increasing use of executive agreements to bypass the treaty procedure, and the unilateral executive use of force beyond merely protecting American citizens contributed to the evisceration of the limitations on executive power. ${ }^{59}$ Observers as diverse as author James Bryce, editor E.L. Bodkin, and military strategist Captain Alfred Thayor Mahan worried that the Constitution was inconsistent with these new imperial aspirations. ${ }^{80}$

A critical theoretical transformation began to unfold during these early years of globalism. Inherent presidential emergency power to meet crises began to emanate from within the Constitution and was no longer an extra-constitutional assertion of authority. President Theodore Roosevelt ar-

56. L. HARTZ, supra note 55, at 37 (describing American sense of mission as curiously Hebraic kind of separation).

57. From a broader perspective, the political, cultural and geographic separation and independence of America from Europe fed the sense of individual autonomy underlying liberal constitutionalism and the separation between public and private.

58. This ethos leads us to respond to fears and perceived crisis, by seeking to remove the alien danger from our midst. We refuse to perceive the threat as part of our culture and instead seek to externalize the danger. This sense of distinctiveness brought us the Palmer Raids, the Korematsu case, and, as Louis Hartz has noted, "made the deportation approach to communism quite instinctive." $L$. HARTZ, supra note 55, at 301 .

59. A. SCHLESINGER, supra note 4, at 85-91; Lafeber, The Constitution and U.S. Foreign Policy: An Interpretation, in A Less Than Perfect Union: Alternative Perspectives on the U.S. Constitution 221, 229-34 (J. Lobel ed. 1988).

60. Lafeber, supra note 59 , at $229-34$. 
ticulated the relativist theory of executive power: "Occasionally great national crises arise which call for immediate and vigorous executive action, and in such cases it is the duty of the President to act upon the theory that he is the steward of the people."B1 Roosevelt, unlike Jefferson, grounded this emergency power on a notion of inherent Constitutional authority, stating that the President had the "legal right to do whatever the needs of the people demand, unless the Constitution or the laws explicitly forbid him to do it."

The Supreme Court provided encouragement to the theory of inherent executive constitutional power to meet exigencies. In 1890, in the course of ruling that the President had the power to provide the Justices with personal bodyguards, the Court noted that the President possessed broad, implied, constitutional powers beyond the execution of treaties and congressional acts. ${ }^{\text {ss }}$

The scholarly community also recognized that America's new role required constitutional changes in the traditional liberal model. For an astute academic such as Woodrow Wilson, the assertion of power abroad "changed the balance of [constitutional] parts," projecting the President "at the front of government." According to Wilson, the traditional theory of the Constitution was premised on Newtonian science, a paradigm that viewed the universe as composed of opposite forces balancing each other to create symmetry and order. ${ }^{65}$ The metaphor of Newtonian physics underscored a dualist, liberal conception of politics and constitutional law. ${ }^{68}$ Wilson, recognizing the constitutional transformation wrought by rising American power, substituted Darwin for Newton, elastic adaptation and modification to environment for formalistic dualities, as the mainspring of American constitutionalism. Wilson thus provided an intellectual framework for the practical shading of legal boundaries limiting executive power.

\section{The Cold War and Its Legacy of Declining Restraints Upon ExeCutive EMERgency PoWers}

The process that started at the end of the nineteenth century culminated after World War II. The assault on the liberal paradigm occurred on several levels. First, the assumption that non-emergency, peacetime conditions were the normal state of affairs and that emergency was an excep-

61. T. ROOSEvelt, Theodore Roosevelt, An AUtobiography 464 (1913).

62. Id.

63. In re Neagle, 135 U.S. 64 (1890).

64. W. WiLson, ConstTtutional Government in THE UNITED States 59 (1908).

65. Id. at 55. Newton's famous third law of the physical universe, "to every action there is always opposed an equal reaction: or the mutual actions of two bodies upon each other are always equal, and directed to contrary parts," parallels the notion of separation of powers and checks and balances.

66. P. Goldstene, The Collapse of Liberal EMPIRE: Science and Revolution in the TWENTIETH CENTURY 11-12 (1977). 
tional condition became invalid. Second, modern Presidents rejected the Lockean-Jeffersonian perspective on executive use of emergency power in favor of a view that the Constitution provided for inherent executive power to meet any perceived emergency. Third, the government concluded that the legislature ought to provide for emergency power instead of requiring the executive to act without legal authority at the peril of hindsight scrutiny. Fourth, the replacement of a formalist intellectual framework with legal realism further supported the judiciary's contribution to the decline of distinctions created during the eighteenth and nineteenth centuries.

\section{A. A Perpetual State of Emergency, or "There's No Such Thing As Normal Times Anymore"}

The United States' new role as the world's dominant superpower fed an obsession with crisis. American dominance altered our notion of national security. Every challenge to United States hegemony anywhere in the world began to be perceived as a threat to national security. Those perceived threats to United States power generated a profound sense of crisis, ${ }^{68}$ leading William Fulbright and others to argue that traditional democratic separation of powers principles had to yield to the need for strong executive power to meet the new situation and maintain United States power. ${ }^{68}$

National Security Council (NSG) Paper 68, issued in April 1950 as

67. Hearings Before the Senate Special Comm. on the Termination of the National Emergency, 93rd Cong., 1st Sess 83 (1973) [hereinafter National Emergency Hearings] (testimony of Prof. G. Casper).

68. Arthur Schlesinger writes, "The belief that the world was greatly endangered by communism had generated a profound conviction of crisis in the U.S.; and the conviction of crisis had generated a foreign policy that placed the separation of powers prescribed by the American Constitution under unprecedented, and at times unbearable strain." A. Schlesinger, supra note 4, at 163. Schlesinger refers to this sense of crisis as bordering on neurosis, as engendering "delusions bred by crisis," a foreign policy "under the hypnosis of crisis," or "a sense of omnipresent crisis." Id. at 164.

Schlesinger analogizes the United States perspective to the state of mind of the Roman empire:

There was no corner of the known world where some interest was not alleged to be in danger or under actual attack. If the interests were not Roman, they were those of Rome's allies; and if Rome had no allies, then allies would be invented . . . Rome was always being attacked by evil-minded neighbors, always fighting for a breathing space.

Id. at 184 (quoting A. Schumpter, IMPERIalism and Social Classes 51 (1955).

69. "The price of democratic survival in a world of aggressive totalitarianism is to give up some of the democratic luxuries of the past." Fulbright, American Foreign Policy in the 20th Century Under an 18th-Century Constitution, 47 Cornell L.Q. 1, 7 (1961); see S. Hoffman, Gulliver's Troubles?, or the Setting of American Foreign Policy (1968); W. Lippmann, The Public PhiLosophy 23-24, 29, 48 (1955); see also T. BaIley, The MAN IN THE Street 13 (1948) ("Yielding some of our democratic control of foreign policy is the price that we may have to pay for greater physical security."); see generally S. REP. No. 797, 90th Cong., 1st Sess. 6 (1967) (perception of crisis is most important cause of executive assertion of virtually unlimited war power and congressional acquiescence); Freidman, supra note 26, at 237 (expansion of executive power tied to perception of crisis). Similarly, the use of CIA covert operation was tied to a perception of crisis. The Central Intelligence Agency Act of 1949 provided for the expenditure of unaudited funds, "for objects of a confidential, extraordinary or emergency nature." Act of June 20, 1949, § 10(b), 65 Stat. 208 (1949). 
"the first comprehensive statement of a national strategy after World War II," "70 foresaw "an indefinite period of tension and danger."71 In response, the NSC called for a massive military buildup, and, as President Truman later wrote, "a great change in our normal peacetime way of doing things." "72 As Truman recognized, the strategy outlined in NSC-68 could not be implemented without a major crisis. Several months later, the Korean War provided such a crisis.

On December 16, 1950, President Truman declared a national emergency in response to the developing Korean conflict. ${ }^{73}$ That national emergency remained in effect for almost twenty-five years, triggering extraordinary presidential powers to "seize property and commodities, organize and control production, call to active duty 2.5 million reservists, assign military forces abroad, seize and control all means of transportation and communications, restrict travel, institute martial law and in many other ways, manage every aspect of the lives of all American citizens." "74 That the fighting in Korea had terminated almost ten years earlier did not prevent President Kennedy from utilizing Truman's emergency proclamation to provide the legal predicate for the embargo against Cuba in $1962 . .^{75}$

The assumptions underlying NSC-68 have been repeated frequently, ${ }^{76}$ most recently in the Iran-Contra scandal. Justifying his covert aid to the Nicaraguan contras in defiance of congressional will, Oliver North argued at the Iran-Contra congressional hearings, "[T]his nation is at risk in a dangerous world." ${ }^{\prime 7}$ The executive had to secretly aid the contras because

70. This was Senator Henry Jackson's characterization of NSC-68. S. AMBrose, RiSE To Globalism 190 (1971); see also LaFeber, supra note 59, at 222 (NSG-68 became the blueprint of U.S. policy after 1950).

71. S. AMBrose, supra note 70, at 190 . In 1947, three years before NSC-68 was promulgated, George Kennan published an extremely influential article, The Sources of Soviet Conduct, 25 ForEIGN AFF. 566 (1947), which assumed a continual state of crisis brought about by Soviet expansionism. Id. at 167-68 (1971). Kennan's article was published anonymously.

72. S. AMBrose, supra note 70 , at $189-91$.

73. Proclamation No. 2914, 15 Fed. Reg. 9029 (1950).

74. S. REP. No. 1170, 93rd Cong., 2d Sess. 2 (1974).

75. Regan v. Wald, 468 U.S. 222, 226-27 (1984) (citing Proclamation No. 3447, 3 C.F.R. 157 (1959-1963)). In addition to the Korean War emergency proclamation, three other declarations of emergency remained in force until the mid-1970s: President Franklin Roosevelt's declaration of emergency on March 9, 1933, to cope with the banking crisis, Act of Mar. 9, 1933, Pub. L. No. 1, 42 Stat. 1 (1933); and the emergencies declared by Richard Nixon in 1970 and 1971 to deal with the Post Office strike and to implement currency and foreign trade restrictions. Proclamation No. 3,972, 3 C.F.R. 473 (1970); Proclamation No. 4,074, 3 C.F.R. 60 (1971).

76. In 1970, the Nixon Administration was asked whether there was still a need for the emergency powers triggered by Truman's proclamation. The administration responded:

We believe the said authority made available by virtue of the 1950 proclamation has been needed during the past two decades and is still needed. This continuing need results from the very acts and threats of aggression which the U.S. and its allies have faced since 1950.

National Emergency Hearings, supra note 67, at 65 (statement of acting Assistant Secretary of State, H.G. Torbert, on behalf of the Nixon Administration).

77. Joint Hearings Before the House Select Comm. to Investigate Covert Arms Transactions With Iran and the Senate Select Comm. on Secret Military Assistance to Iran and the Nicaraguan Opposition, 100th Cong., 1st Sess. I-100-07 (1987) (testimony of O. North) [hereinafter Iran-Contra 
"there was a disaster at hand," "we will be overwhelmed," and in less than twenty years will have to construct a "Berlin-type wall along the Rio-Grande."78 According to NSC Adviser John Poindexter, the view from the White House was that if Nicaragua was lost, Central America and the Panama Canal would be immediately endangered. ${ }^{79}$ Congressman Henry Hyde and others raised the specter of Neville Chamberlain and Munich to justify the executive's need to unilaterally aid anti-communist Nicaraguan rebels. ${ }^{80}$

Ironically, the era of our greatest international power and security has coincided with a mentality of great fear for our own national survival. ${ }^{\mathbf{1 1}}$ As Professor Gerhard Casper has argued, this sense of emergency "fosters . . . a mentality which suggests that we live in a garrison state, . . . we are in a state of alertness at all times. There is no such thing as normal times any more."82

Although leaders' interests in manipulating the body politic to support a massive military buildup and intervention overseas are largely responsible for the creation of this imagery of crisis, ${ }^{83}$ structural changes in the world are also responsible. Most ominous is the development of atomic weapons, which has brought about pervasive anxiety. ${ }^{84}$ Politically, "[ $\left.t\right]$ he nuclear face-off has ushered in an age of the chronic emergency," leading some commentators to argue that it is no longer reasonable or appropriate "to distinguish between the emergency powers of the executive and the

Hearings].

78. Id. at I-150, I-194, II-67 (testimony of O. North).

79. Id. at I-100-08, I-222-23. Senator Cohen reflected the atmosphere of emergency permeating our national life when he commented on the erection of barricades in front of Congress and the White House, stating, "These stone barricades are not only safeguards for all of us, but they are also symbols of the dangerous times in which we live. . . ." Id. at I-255.

80. House Sel.ect Comm. to Investigate Covert arms Transactions with Iran and Senate Select Comm. On Secret Military assistance to Iran and the Nicaraguan OppOSITION, REPORT OF THE CoNGRessional CoMms. Investigating the Iran-Contra AfFairs, S. Rep. No. 216, H. Rep. No. 433, 100th Cong., 1st Sess. 667, 669 (1987) [hereinafter Iran-Contra Report] (supplemental views of Rep. Hyde).

81. As former Secretary of State Dean Acheson said in 1953, "the purpose of our foreign policy is to maintain and foster an environment in which our national life and individual freedom can survive and prosper." D. Acheson, This Vast External Realm 19 (1973). Acheson went on to argue that our national survival was facing a grave danger from the Communist threat. President Kennedy returned to the imagery of survival when, in his Inaugural address, he asserted that "we shall pay any price, bear any hardship . . . in order to assure the survival and success of liberty." To TURN THE Tide: Selection of President Kennedy's Public Statements 6, 7 (J. Gardner ed. 1962) (quoting President Kennedy's Inaugural Address, Jan. 20, 1961).

82. National Emergency Hearings, supra note 67, at 83; see also R. RANkin \& W. DallmaYR, Freedom and Emergency Powers IN THE Cold War 2 (1964) (ours is an "age of permanent crisis"); Miller, supra note 20; Robinson, The Routinization of Crisis Government, 63 YALE REv. 161 (1973).

83. Justice William $O$. Douglas once noted that "subconsciously we are not reacting to external threats, but to a desire to extend our own economic realm and our political zones of action." W. Douglas, International Dissent: Six Steps Toward World Peace 47 (1971); see also N. Chomsky, Turning the Tide 66-72, 85-89 (1985) (describing United States view that we are "a pitiful, helpless, giant" as a mechanism "undoubtedly believed at some level of consciousness," but cynically invoked to justify intervention abroad).

84. R. May, The Meaning of ANXIETy 12 (1977). 
non-emergency policy prerogatives of the legislature." ${ }^{85}$ In a nuclear age dominated by two superpowers, frequent crises have been substituted for direct military confrontation between the two great power blocs. ${ }^{88}$

The threat of annihilation has coincided with a prevalence of civil wars that is unique in history. ${ }^{87}$ Rather than risk total destruction in direct confrontation, the major powers have channelled their conflict into proxy, often covert, wars between different factions within foreign states. ${ }^{88}$ This changing character of warfare has led to a blurring of distinctions: between war and peace, private armies and state agents, transnational and civil war, civilian and military forces. ${ }^{89}$ A Senate committee noted in 1976, "The recognizable distinctions between declared war and credible peace have been blurred throughout these [post-war] years by a series of regional wars and uprisings, in Asia, the Middle East, Latin America, Europe, and Africa." 190 More recently, the Iran-Contra scandal demonstrated that in the conduct of covert, national security operations, "[t]he important line between public and private action has become blurred as the result of the secret use of private institutions and individuals by intelligence agencies."

Most importantly, this new era of undeclared war and intervention into civil wars has led to an almost perpetual state of United States involvement in armed conflict around the world. The nation is legally at peace with Nicaragua, yet its agents have mined Nicaraguan harbors and

85. Goldstein, The Failure of Constitutional Controls Over War Powers in the Nuclear Age: The Argument for a Constitutional Amendment, 40 STAN. L. Rev. 1543, 1546 (1988); see also Brezinski, Forging a Bipartisan and Strategic Approach to Foreign Affairs, 43 U. Mrami L. REv. 5, 9 (1988) (nuclear warfare complicates traditional separation of power).

86. Waltz, The Stability of a Bipolar World, 1964 DaEdalus 884; see J. Spanier, Games NaTIONS Play 196 (4th ed. 1981).

87. Laurd, Civil Conflicts, in Modern InTERnational. Relations in INTERNational ReguLation of CiviL Wars 8 (E. Laurd ed. 1972). The New York Times has reported that between 1946 and 1959, over 1,200 internal disturbances that could be considered war broke out. Eckstein, Introduction: Toward the Theoretical Study of War, in InTERnal. War: Problems and APProaches 3 (H. Eckstein ed. 1964).

88. Falk, Janus Tormented: The International Law of Internal War, in INTERNATIONAL Aspects of Civil StYle 189 (J. Rosenau ed. 1964).

89. Harry Truman responsed to the Court's decision in Youngstown Sheet $\mathcal{E}$ Tube Co. v. Sawyer:

Whatever the six justices of the Supreme Court meant by differing opinions about the constitutional powers of the President, they must always act in a national emergency. We live in an age when hostilities begin without polite exchanges of diplomatic notes. There are no longer sharp distinctions between combatants and noncombatants, between military targets and the sanctuary of civilian areas. Nor can we separate the economic facts from the problems of defense and security. [The] President, who is Commander in Chief and who represents the interests of all the people, must be able to act at all times to meet any sudden threat to the nation's security.

G. Stone, L. Seidman, C. Sunstein \& M. Tushnet, Constitutional Law 360 (1986) (quoting 2 H. Truman, Memoirs: Years of Trial and Hope 478 (1956)).

90. S. REP. No. 755, 94th Cong. 2d Sess. I-8 (1976) [hereinafter CHURCH CoMM. REP.]. While undeclared civil warfare was certainly present during the 18 th and 19 th centuries, the overwhelming predominance of these forms of warfare in the late twentieth century supports the Committee's statement.

91. Id. at 16 . 
armed, trained, and directed a force attacking Nicaraguan territory. In these circumstances, the legal term, "peace," has little or no significance. The new forms of warfare curiously present similarities to the style of warfare existing in the Middle Ages, an era in which private and public armies were not distinct, peace and war were not distinct legal regimes, and intermittent warfare was constant. ${ }^{92}$

\section{B. Doctrinal Changes}

The effect of both the ideology and reality of permanent crisis has dramatically transformed the constitutional boundaries between emergency and non-emergency powers. First, the premise that emergency was a short, temporary departure from the normal rule of law is no longer operative. ${ }^{93}$ Emergency rule has become permanent.

Second, the requirement that the President act in an emergency with an awareness that her action is unconstitutional has been discarded. Instead, modern presidents have developed relativistic theories of executive power premised upon finding broad emergency power within the constitutional framework. Three key constitutional sources have emerged: the "executive power" clause, ${ }^{94}$ the Commander in Chief clause, ${ }^{95}$ and the executive's implied power over foreign affairs.

Presidents such as Theodore Roosevelt, Harry Truman, and Richard Nixon have asserted that since Article I limits congressional power to those powers "herein granted," while Article II's grant of "executive power" has no such limitation, the President has inherent power to do either anything necessary to preserve the United States, or, even more broadly, anything not explicitly forbidden by the Constitution. ${ }^{96}$ Even

92. Lobel, The Rise \& Decline of the Neutrality Act: Sovereignty \& Congressional War Powers in United States Foreign Policy, 24 HaRv. INr'L L.J. 1, 6-11 (1983).

93. As Professor Cotter has noted, "What Edwin S. Corwin . . . has called the American conception of war or emergency . . . that it is something arising outside of the normal course of events, something which is violently and arbitrarily projected across it, . . . will just no longer do as a guide for emergency government in the United States." National Emergency Hearings, supra note 67, at 23.

94. U.S. CoNST., Art. II, $\$ 1$.

95. U.S. ConsT., Art. II, $\$ 2$.

96. See T. Roosevelr, supra note 61, at 389. Harry Truman argued, "The Power of the President should be used in the interest of the people and in order to do that the President must use whatever power the Constitution does not expressly deny him." M. Cunliffe, AMEriCan PRESIDents AND The Presidency 343 (2d ed. 1976) (quoting President Truman); see A. Schlesinger, supra note 4, at 362-66. The Executive's argument to the District Court in the Youngstown Sheet and Tube case relied on a view of inherent executive emergency power based on the distinction between Articles I and II. J. SMrTH \& C. Correr, supra note 30, at 135 (argument of Assistant Attorney General Baldridge that Article II of Constitution "did not limit the powers of the President"). For a more recent exposition of the same view, see Cooper, What the Constitution Means By Executive Power 43 U. Miami L. Rev. 165 (1988) (Assistant United States Attorney General Charles Cooper's remarks that founders understood executive power as conferring broad authority beyond mere execution of the laws).

The argument that Article I and Article II powers can be distinguished in this manner is not new, having been made by Alexander Hamilton as early as 1793 in his Pacificus essays. A. Hamilton, 
though this "executive power" clause argument has been condemned by commentators and some courts, ${ }^{97}$ the executive has continued to rely on it.

This view of inherent executive powers dissolves the distinction between emergency power and normal lawful power. The abstract concept "executive power" has no fixed or limited content, ${ }^{\mathbf{8 8}}$ as Daniel Webster recognized in an eloquent 1835 address to the Senate:

It is true, that the Constitution declares that the executive power shall be vested in the President; but the first question which then arises is, What is executive power? What is the degree, and what are the limitations? Executive power is not a thing so well known, and so accurately defined, as that the written constitution of a limited government can be supposed to have conferred it in the lump. What is executive power? What are its boundaries?

The Executive has also justified broad emergency power through resort to the Commander in Chief clause of Article II. The traditional limit of the Commander in Chief's power to that necessary to repel sudden attack or resist invasion until Congress has declared $\operatorname{war}^{\mathbf{1 0 0}}$ no longer controls after the Cold War. The Justice Department argued that the President had the unilateral power to send troops to Vietnam because the interdependence of the twentieth century world meant that all warfare anywhere in the world might "impinge directly upon the nation's security."101 Therefore, modern Presidents have articulated a constitutional power to send forces into combat whenever they detect threats to national security. Under this model, the Commander in Chief's powers, in Dean Rusk's approving words, "are as large as the situation requires."102 This vision of

Pacificus No. 1, in The Papers of Alexander Hamilton 33, 38-40 (H. Syrett ed. 1969). James Madison, urged on by Secretary of State Jefferson, disputed Hamilton's view of broad executive power, although he did not directly challenging Hamilton's Article I/Article II distinction. Winterton, The Concept of Extra-Constitutional Executive Power in Domestic Affairs, 7 Hastings Const. L.Q. 1, 26-28 (1979) (and sources cited therein). In fact, both Hamilton and Madison recognized that the Executive's power to promulgate the Neutrality proclamation could be premised on his duty to faithfully execute the laws. Id. Professor Corwin argued that the records of the Constitutional Convention make it clear that the purposes of the first clause of Article I were simply to settle the question of whether the executive branch should be plural or single and to give the executive a title. Id. at 26 (quoting Corwin).

97. Id. at 24-25 \& n.160. See M. Marcus, Truman and the Steel Seizure Case: The Limits of Presidential. Power 124-26 (1977) (Baldridge's argument in Steel Seizure Case so extreme that it was disowned by President).

98. Winterton, supra note 96 , at 27.

99. Myers y. United States, 272 U.S. 52, 229-30 (1926) (Reynolds, J., dissenting) (emphasis in original) (quoting from 4 D. WEBSTER, THE WORKS OF DANIEL. WEBSTER 186 (1851)).

100. For the framer's views, see Van Alstyne, supra note 26, at 7-8; Berger, supra note 26 , at 42-44; Lofgren, supra note 26 , at 676 .

101. Office of the Legal Adviser, Dept. of State, The Legality of United States Participation in the Defense of Viet Nam, 75 YALE L.J. 1085 (1965); see also Rogers, supra note 25, at 1197 (rationale behind the concept to repel sudden attacks supports the broader position that "in emergency situations, the President has the power and the armed responsibility to use force to protect the nation's security"); Rostow, Great Cases Make Bad Law, supra note 25.

102. A. Schlesinger, supra note 4, at 169. As Republican leader Everett Dirksen told the Sen- 
the Commander in Chief clause merges war and peace, offensive action and defensive conduct. If any threat to United States security around the world activates the executive's war powers, then the distinction between the executive emergency power to repel an attack and congressional power to authorize the introduction of U.S. forces into hostilities loses significance. ${ }^{103}$

Finally, the executive branch has often relied on the President's generic and ill-defined power as "the sole organ of foreign affairs," articulated by dicta in United States v. Curtiss-Wright Export Corp., ${ }^{104}$ to justify power to act in emergency situations. ${ }^{105}$ Recent administrations have asserted forcefully that the Constitution limits congressional authority to restrain the exercise of the President's power as the "sole organ" of foreign affairs power. ${ }^{108}$

In sum, as emergency scenarios became the norm, interpretations of the foreign affairs power, the Commander in Chief clause, and the executive power clause developed so that the exercise of power necessary to meet the constant state of crisis was no longer extra-constitutional. The President no longer has to weigh the need for action against the lack of constitutional authority to act, because the new constitutional flexibility allows the executive to respond to virtually all exigencies within the constitutional order. ${ }^{107}$ Executive legality and illegality have become muddled; former

ate in 1967, his review of Supreme Court precedent yielded "no delimitation on the power of the Commander in Chief under the Constitution." Id. at 170.

103. The only boundary conceivably limiting executive use of force would be a requirement that the President articulate some rational or colorable claim that United States national security was threatened, a requirement that would be met easily in most cases.

104. 299 U.S. 304, 320 (1936). In the course of upholding a broad congressional delegation of authority to the President to prohibit arms sales to other nations, the Court noted that in addition to the delegated legislative authority, the President had "plenary and exclusive power . . . as the sole organ of the federal government in the field of international relations . . . which does not require as a basis for its exercise an Act of Congress." 299 U.S. at 319-20. That sweeping statement was unnecessary to the Court's relatively narrow upholding of the congressional enactment. See Youngstown Sheet \& Tube Co. v. Sawyer, 343 U.S. 579, 636 n.2 (1952) (Jackson, J., concurring) (deeming much of the Court's Curtiss-Wright opinion dictum). Reliance on Curtiss-Wright for the proposition that the President has an exclusive, independent power to conduct foreign affairs is therefore unwarranted. IranContra Report, supra note 80, at 389-90.

105. Iran-Contra Report, supra note 80 , at 388 (various witnesses at Iran-Contra hearing, including North and Poindexter, invoked Curtiss-Wright to support broad presidential power).

106. See, e.g., U.S. Intelligence Agencies and Activities: Risks and Control of Foreign Intelligence: Hearings Before the House Select Committee on Intelligence, 94th Cong., 1st Sess. 1729-34 (1975) (statement of Mitchell Rogorin, Special Counsel to Director of CIA under President Ford); Hearings Before the Senate Select Comm. on Intelligence, 96th Cong. 2d Sess. 15-19 (1980) (statement of Stansfield Turner, Director of the CIA under President Carter) (requirement of prior notification of all covert actions would amount to excessive intrusion into executive's constitutional powers). The Intelligence Community 714 (T. Fain, K. Plant \& R. Milloy eds. 1977) (quoting Memorandum to Laurence Houston, General Counsel to the CIA, on the constitutional and legal basis for covert activities of the GIA). Intelligence Oversight Act of 1988 Hearings Before the House Comm. on Foreign Affairs, 100th Cong., 2d Sess. 114-15 (1988) (testimony of Mary Lawton, counsel for intelligence policy, Justice Department) (requiring 48 hours notice of all covert action, "by tying the President's hands too rigidly in an area committed to him by the Constitution-the handling of the foreign affairs of the nation . . . steps over the line of separation of powers").

107. National Emergency Hearings, supra note 67, at 258 (statement of committee staff director 
President Nixon even argued that our national security concerns now allow that when "the President does it, that means that it is not illegal."108 Flexibility, not strict or mechanical limits, is the constitutional command in this new age of emergency.

\section{The Rise of Legislative Delegation of Emergency Power to the President}

Parallel to the rise of constitutionally-derived executive power to respond to crises was the increasingly vast delegation of emergency power by Congress to the President. Many legislators thought it preferable to provide for emergency rule by law instead of either requiring the President to act illegally under the Jeffersonian-liberal model or relying upon the inherent power of the executive.

Congress sought to provide for executive emergency power by heeding Machiavelli's warning that a republic ought to provide by law "for every emergency, [by] having a remedy for every emergency and fixed rules for applying it."109 According to this outlook, the Constitution's failure to provide for broad executive emergency power would be best remedied by legislation providing a framework for emergency rule.

In 1948, Clinton Rossiter's book, Constitutional Dictatorship, outlined the need for legislation to respond to the new crisis conditions. ${ }^{110}$ Rossiter presciently concluded that in the atomic age, "[t]he use of constitutional emergency powers may well become the rule and not the exception."111 Recognizing that the nation's destiny "will rest in the capacity of the Presidency as an institution of constitutional dictatorship,"112 Rossiter advocated tightening, limiting, and simultaneously strengthening emergency powers. A "criterion of cardinal importance" was for Congress to adopt a carefully elaborated scheme and procedure for the suspension of rights and invocation of executive power in time of emergency. According to Rossiter,

\section{[A]ll uses of emergency powers and all readjustments in the organ-}

William Miller that in the absence of any objective definition of national emergency, "if the President says so, it is a national emergency").

108. N.Y. Times, Mar. 20, 1976, at A16, col. 5. According to Nixon, the only "dividing line" between constitutional and unconstitutional conduct in the area of national security is the President's judgment. Nixon justified his view by arguing that what is legal or illegal cannot be decided without reference to the circumstances under which the President concludes the activity is necessary. N.Y. Times, Mar. 12, 1976, at 14, col. 2. Nixon went to incredible lengths to invoke Lincoln's relativistic view that the Civil War made constitutional certain executive actions that would otherwise have been unlawful, claiming that the ideological division in the 1960's tore the nation apart in a fashion analogous to the Civil War. N.Y. Times, Mar. 20, 1976, at A16, col. 6.

109. 1 N. Machiavel.ir, The Discourses ch. 34 (L. Walker trans. 1950), quoted in J. SMITH

\& C. CotTER, supra note 30 , at 8.

110. C. Rossiter, Constiturional. Dictatorship (1948).

111. Id. at 297.

112. Id. at 309 . 
ization of the government should be effected in pursuit of constitutional or legal requirements. In short, constitutional dictatorship should be legitimate. It is an axiom of constitutional government that no official action should ever be taken without a certain minimum of constitutional or legal sanction. This is a principle no less valid in time of crisis than under normal conditions. ${ }^{113}$

Professor Edwin Corwin reiterated Rossiter's theme in the 1950's. ${ }^{114}$ For Corwin, the lesson of Youngstown Sheet $\mathcal{E}^{2}$ Tube Co. v. Sawyer, ${ }^{115}$ in which the Court invalidated President Truman's seizure of steel mills, was that "just as nature abhors a vacuum, so does an age of emergency. Let Congress see to it, then, that no such vacuum occurs. The best escape from presidential autocracy in the age we inhabit is not, in short, judicial review, which can supply only a vacuum, but timely legislation."116

In response to the post-war situation outlined by Rossiter and Corwin, Congress enacted hundreds of statutes providing for broad emergency power. By the 1970s, some 470 such statutes existed, delegating power to the executive over virtually every facet of American life. ${ }^{117}$ Some of the legislation contained positively draconian provisions. For example, the Internal Security Act of 1950 authorized the President to detain all persons whom the government had a "reasonable ground" to believe "probably" would commit or conspire to commit acts of espionage or sabotage. ${ }^{118}$ While the detained person was entitled to an administrative hearing and appeal, the Act did not provide for trial before an Article III court, nor for the confrontation and cross-examination of adverse witnesses. Moreover, in most of the emergency legislation, vague terms ${ }^{119}$ triggered execu-

113. Id. at 300 (emphasis in original).

114. E. Corwin, The President, Office and Powers 1787-1957 157 (4th ed. 1957); see Corwin, The Steel Seizure Case: A Judicial Brick without Straw, 53 Col. L. Rev. 53, 66 (1953).

115. Youngstown Sheet \& Tube v. Sawyer, 343 U.S. 579 (1952) (holding unconstitutional President Truman's seizure of steel mills based on inherent executive emergency power).

116. E. CoRwin, supra note 114, at 157. See Corwin, supra note 114, at 66 ; see also J. SMITH \& C. CotTer, supra note 30 , at 13 (urging provision of legislation sufficient to meet emergency need).

117. S. ReP. No. 1170, 93d Cong., 2d Sess. 2-3 (1974).

118. Internal Security Act of 1950, Pub. L. No. 81-831, Title II, 64 Stat. 987 (1950) (repealed in 1971). R. Goldstein, Political Repression in Modfrn America: From 1870 to the Prfsent 322-24 (1978). Congress appropriated $\$ 775,000$ in 1952 to set up six detention camps in Arizona, Florida, Pennsylvania, Oklahoma and California. Id. at 324. The emergency detention provision of the Internal Security Act was drawn up with the aid of ACLU attorneys and supported by Senate liberals such as Hubert Humphrey, Wayne Morse and Paul Douglas. Id. at 366 . Indeed, the $\Lambda \mathrm{ct}$, as repressive and dangerous as it might seem in retrospect, caused concern to the FBI, which had been maintaining a list of persons to arrest under a more flexible Justice Department plan that could be invoked in a time of "threatened invasion" against "dangerous persons," a practice which continued after passage of the Act. Although the ISA was finally repealed in 1971, forms of emergency detention have continually reappeared in executive plans, judicial decisions, and most recently in the Northaided FEMA plan. B. BRADLFE, supra note 1, at 132 (draft executive order proposed by FEMA plan said to have contained provision for "alien control" and "detention of enemy aliens"); see also United States v. Salerno, 107 S. Gt. 2097, 2102 (1987) (dictum on constitutionality of aliens' internment during wartime).

119. National Emergency Hearings, supra note 67, at 256 (statement of Mr. Miller). 
tive power for unspecified lengths of time. State legislatures followed the federal example, delegating broad emergency power to governors. ${ }^{120}$ Rossiter's admonitions that emergency powers should be narrowly drawn and tightly controlled were simply ignored.

While these legislative delegations of emergency authority were often excessive and uncontrolled, the fundamental problem with the effort to codify, systematize, and legalize the exercise of executive emergency authority was its attempt to eliminate the tension between law and necessity that liberal thought presumes. By providing legislation to address every conceivable emergency situation, emergency power inevitably becomes routinized, normal, and by definition, lawful.

\section{The Court's Role and the Rise of Legal Realism}

The judiciary also played an important role in transforming the executive's emergency power. The Curtiss-Wright Court's dicta about the President's "plenary and exclusive power" over matters connected with foreign affairs ${ }^{121}$ lent legitimacy to the doctrine of inherent and unilateral executive power to conduct foreign affairs.

Furthermore, the Court's wartime detention rulings adopted an extremely deferential 'reasonableness' standard of review, concluding merely that the Court could not "reject as unfounded" the military's claim of necessity. ${ }^{122}$ Many lower federal courts simply refused to review the validity of actions taken during a national security emergency. ${ }^{123}$ To the extent

120. See, e.g., ALA. ConE $\S \S 31-9-1-24$ (1987) (Governor given broad emergency powers upon declaration of emergency where attack on United States is threatened or natural disaster has occurred within State, threatening welfare of inhabitants (§ 31-9-8)); CAl. Gov'r ConE $\$ \S 8555-8668$ (West 1980) (Governor given broad emergency powers where attack on the United States or state is probable ( $\$ 8558(a)$ ), or where she has proclaimed emergency due to disaster or extreme peril to persons and property, and local authorities request assistance or she finds them unable to cope with emergency (pursuant to $\S 8625$ )); DEI.. CODE ANN. tit. 20, §§ 3101-33 (1985) (Governor given broad emergency powers upon declaration of public disorder, disaster or emergency affecting life, health, property or public peace (\$§ 3125, 3126)); FL.A. STAT. ANN. $\$ \S 252.31-.55$ (West 1975 \& Supp. 1988) (Governor given broad emergency powers upon declaration that threat that may result in substantial injury to property or people is imminent ( $\$ 252.36(2)$ ); IND. CoDE ANN. $\S \S 10-4-1-1--28$ (Burns 1988) (Governor given broad emergency power upon declaration of imminent threat of widespread or severe damage to life or property (§ 10-4-1-7)); Iowa Conk ANN. \$§ 29.c.1-20 (West 1978 \& Supp. 1988) (Governor given broad emergency powers upon declaration that people or property are threatened by either public disorder substantially interfering with public peace $(\S 29 . c .3)$ or threatened disaster $(\S$ 29.c.6)); N.Y. Exkc. LAw $\$$ 20-29(d) (McKinney 1982) (Governor given broad powers where she declares that a threat of widespread or severe damage to life or property may be imminent $(\S 28)$; chief executives of local areas given broad emergency powers where they have reasonable apprehension of immediate danger from disaster, noting, catastrophe or similar public emergency (\$24)); VA. CODE ANN. \$\$ 44-146.13-.28 (1986) (Governor given broad emergency powers where she declares (pursuant to $\$ 44-146.17(7)$ ) threat of condition of sufficient severity and magnitude to require disaster assistance or of "occurrence of such severity or magnitude that governmental action beyond that contemplated by existing law is required").

121. 299 U.S. 304, 320 (1936). See supra note 104.

122. Korematsu v. United States, 323 U.S. 214, 218-19 (1944); Hirabayashi v. United States, 320 U.S. 81 (1943) (standard is whether government has "reasonable ground for believing that the threat is real). But of. Duncan v. Kahanamoku, 327 U.S. 304, 336 (1946) (Stone, J., concurring).

123. See, e.g., Sardino v. Federal Reserve Bank of N.Y., 361 F.2d 106, 109 (2d Cir. 1966), 
that the courts reviewed the exercise of emergency powers, they read Congress' delegations broadly and upheld executive authority. ${ }^{24}$ An example of this judicial deference is Sardino v. Federal Reserve Bank of New York. ${ }^{125}$ In upholding the Cuban embargo based on President Truman's declaration of emergency fifteen years earlier during the Korean War, Judge Friendly opined:

While the courts will not review a determination so peculiarly within the province of the chief executive, there can hardly be doubt as to the existence of an emergency today when thousands of. United States troops are in action and many more are in readiness around the globe. ${ }^{128}$

The perception of a "communist menace" provided a sufficient legal basis to exercise emergency power towards Cuba.

Even the bright spot in judicial restriction of executive emergency power-Youngstown Sheet and Tube Co. v. Sawyer ${ }^{27}$-had the effect of muddying the line between emergency and non-emergency power. Although advocates of congressional authority look to Youngstown's invalidation of the President's seizure of the steel mills as the basis for imposing limits on executive authority, ${ }^{128}$ the decision contains the seeds for an expansion of the President's emergency power.

The legal realist perspective of the concurrences of Justice Jackson and Justice Frankfurter, rather than the formalism of Justice Black's majority opinion, now dominates the national security establishment's view of the Constitution. ${ }^{129}$ In contrast to Black's clear conceptual categories of legal

discussed infra at text accompanying notes 125-126; United States v. Yoshida Int'l Inc., 526 F.2d 560, 579, 581 n.32 (C.C.P. 1975) (court will not review Presidential judgment that national emergency exists, although it will review whether President's acts are within statutory authority); Beacon Products Corp. v. Reagan, 633 F. Supp. 1191, 1194-45 (D. Mass. 1986), affd, 814 F.2d 1 (1st Cir. 1987) (whether national emergency as defined by statute existed with respect to Nicaragua in 1984 presents non-justiciable political question); see also Perpich v. United States Department of Defense, No. 87-5345 (8th Cir. Dec. 6, 1988) reh'g en banc granted (8th Cir. Jan. 11, 1989) (WESTLAW, Allfeds Library) (the determination of existence of national emergency involves "central political question").) See generally, C. MAY, supra note 48 (discussing judicial reluctance to adjudicate cases involving executive emergency powers since 1918).

124. United States v. Yoshida, 526 F.2d 560, 573 (C.C.P.A. 1975).

125. 361 F.2d 106 (2d Cir. 1966).

126. Id. at 109 .

127. 343 U.S. 579 (1952).

128. Koh, Why the President (Almost) Always Wins in Foreign Affairs: Lessons of the IranContra Affair, 97 YALE L.J. 1255, 1282-85, 1309 (1988) (Youngstown assumes dialogue and general consensus between Congress and the President about substantive foreign policy ends); Lobel, The Limits of Constitutional Power: Conflicts Between Foreign Policy and International Law, 71 VA. L. REv. 1071, 1119-20 (1985) (Youngstown requires congressional approval of executive action in violation of international law); Glennon, The War Power Resolution: Sad Record, Dismal Promise, 17 LoY. L.A.L. Rev. 657, 661 (1984) (Youngstown supports War Powers Resolution).

129. Casper, Constitutional Constraints on the Conduct of Foreign and Defense Policy: A NonJudicial Model, 43 U. CHI. L. REv. 463, 465-66 (1976). See, e.g., McDougal, Treaties and Congressional Executive Agreements: Interchangeable Instruments of National Policy, 54 YALE L.J. 181, 212, 221 (1945) (arguing against mechanical or formalistic view of Constitution); Rostow, Response, 
and illegal executive activity, the Jackson and Frankfurter concurrences contend that foreign affairs powers under the Constitution must be viewed empirically and fluidly. Presidential powers are "not fixed but fluctuate." 130 Although Jackson strongly rejects the claim of inherent emergency presidential power to act in derogation of congressional will, he recognizes, in the legal realist tradition, that the boundary between executive emergency power and legislative power is fluid in the absence of congressional disapproval. ${ }^{131}$ Frankfurter similarly relies upon Holmes' teaching that "the great ordinances of the Constitution do not establish and divide fields of black and white."132 The Frankfurter concurrence eschews formalism as an impermissible "disregard [for] the gloss which life has written upon" the text of the Constitution. ${ }^{133}$ The Jackson/Frankfurter model is, in effect, an extension of Wilson's exchange of the Newtonian, mechanistic model of separation of powers in favor of a Darwinian vision. ${ }^{134}$

By emphasizing fluid constitutional arrangements between Congress and the President instead of the fixed liberal dichotomies bounding executive power, the legal realist approach to the Constitution and foreign affairs has effectively supported the extension of executive emergency authority. ${ }^{135}$ The Burger and Rehnquist Gourts have subsequently utilized Youngstown to uphold broad assertions of executive power. ${ }^{136}$ There has

61 VA. L. Rev. 797, 798 (1975) (urging flexibility). Brezinski, supra note 85, at 6 (President Carter's National Security Adviser argues that Constitution does not hand down "clear cut guidelines for the process of shaping national security policy," leaving legislative and executive powers "blended" in "inevitably . . . fluid" relationship).

130. 343 U.S. at 635 (Jackson, J., concurring).

131. See Mensch, The History of Mainstream Legal Thought, in The Politics of LAw 18, 31 (Kairys ed. 1981). As Professor Mensch wrote, "The prevailing [realist] pattern is to accept as inevitable and 'in the nature of things' the absence of vacuum-bounded categories. Id. Instead, the boundaries between categories are portrayed as fluid, or "live," meaning that particular examples often will occupy a murky middle position. Thus, the collapse of spheres is not total and the goal is to deal comfortably with a world made up largely of middle positions." Id.

132. 343 U.S. 597 (1952) (Frankfurter, J., concurring).

133. 343 U.S. at 610 .

134. See supra notes $64-66$ and accompanying text.

135. For example, Secretary of State William Rogers opposed the War Powers Resolution as unconstitutional, because "it would attempt to fix in detail," or "freeze" the allocation of power between the President and Congress. S. Rep. No. 220, 93rd Cong., 1st Sess. 18 (1973). See also Meese, Constitutional Fidelity and Foreign Affairs, 43 U. MIAMI L. REv. 223, 224 (1988) (arguing that ambiguity regarding limits of congressional versus executive authority makes struggle to define these limits "more political than constitutional"). Advocates of a forceful assertation of United States power abroad have also eschewed the strict, formal rules restraining the use of force contained in the U.N. Charter in favor of a more fluid, "realistic" perspective. As Ambassador Jeane Kirkpatrick argued in defending the United States invasion of Grenada, "the prohibitions against the use of force in the U.N. Charter are contextual, not absolute." Nanda, The United States Armed Intervention in Grenada's Impact on World Order, 14 GAL. W. INT'L L.J. 395, 418 (1989).

136. Dames \& Moore v. Regan, 453 U.S. 654 (1981). See generally Koh, supra note 128, (discussion of cases upholding broad assertion of executive power). In addition, Jackson's test became even more flexible in Justice Rehnquist's hands in Dames $\mathcal{E}$ Moore. Rehnquist noted that in any particular instance, executive actions fall "not neatly in one of the three pigeonholes, but rather at some point along a spectrum. . . This is particularly true as respects cases such as the one before us, involving responses to international crisis the nature of which Congress can hardly have been expected to anticipate in any detail." 453 U.S. at 669 . Justice Rehnquist relied heavily in Dames $\mathcal{E}^{\circ}$ Moore upon Frankfurter's gloss of a long-continued practice to uphold executive power. 
been a growing gap between the actual conduct of foreign affairs and the Constitution's text and original intent. ${ }^{137}$ Ironically, it is precisely the conservative proponents of executive power who deemphasize the original intent and text in favor of reliance upon historical practice, thereby implementing Frankfurter's admonition not to ignore "the gloss which life" has written on the Constitution. ${ }^{138}$ In modern America, that "gloss" inevitably illuminates executive constitutional power.

The routinization of crises, the rise of inherent executive power, the delegation of vast emergency power, and the sway of legal realism in the courts combined to break down the dichotomies upon which the liberal constitutional tradition was premised. Although a grey area has always accompanied the fixed dividing line between emergency and normalcy, the hazy middle zone has expanded to include most important executive exercises of foreign affairs power, resulting in broad, virtually unchecked presidential power. ${ }^{139}$

\section{The FaILURe of Reform}

The twin disasters of Vietnam and Watergate created pressure to restore the liberal distinctions so critical to the definition and limitation of emergency powers. ${ }^{140}$ Even strong supporters of the growth of executive power during the 1940s and 1950s, such as Arthur Schlesinger and

Another example of the judiciary's reluctance to rely on fixed rules to determine foreign affairs issues is Judge Adams decision in Atlee v. Laird, 347 F. Supp. 689, 707 (E.D. Pa. 1972) (dismissing constitutional challenge to Viet Nam War because non-justiciable issue), affd sub nom., Atlee v. Richardson, 411 U.S. 911 (1973). Judge Adams' rationale was in part based on the fear that "setting forth rules, [might] create a rigid matrix that would unnecessarily restrict the executive sometime in the future." Id.

137. See supra note 26. This gap can also be perceived in Supreme Court decisions which have, since the Pentagon Papers case, consistently upheld executive power as a matter of result, even as they rhetorically adhere to Congressional dominance. Edgar \& Schmidt, Curtis-Wright Comes Home: Executive Power In National Security Secrecy, 21 HaRv. C.R.-C.L. L. Rev. 349, 353 (1986).

138. Shortly after Attorney General Meese's speech extolling a jurisprudence of original intention, I argued a case raising the question of whether the President had the power to terminate a treaty and deprive a citizen of valuable rights under the treaty. I relied heavily on an originalist jurisprudence, while the Justice Department ignored the views of the Founders, focusing instead on recent historical practice. The District Court held that the issue presented a non-justiciable political question. Beacon Products v. Reagan, 633 F. Supp. 1191, 1198-99 (D. Mass. 1986). But cf. Meese, supra note 135 (arguing for strong executive power as matter of original intent). In its report on the War Powers Legislation, the Senate Foreign Relations Committee noted that those supporting war powers legislation emphasized the intent of the framers of the Constitution and the importance of the congressional war power for a system of government based on the separation of powers and checks and balances. Those testifying against the war powers legislation cited historical instances in which the President has used the armed forces without the consent of Congress and the necessity of rapid action under the conditions of the nuclear age. S. REP. No. 220, supra note 26 , at 7 .

139. Mensch, supra note 131; see also Kennedy, supra note 17 , at $1352-53$ (in this stage most situations are "not absolutely one thing or another.") In short, the twilight zone has crowded out the distinction between night and day and constitutes a major part of our foreign policy-constitutional spectrum. With the exception of extreme situations-which the FEMA plan probably represented-"everything is in the middle." Id. at 1352.

140. See supra Part I. 
William J. Fulbright, began to question whether the pendulum had swung too far. ${ }^{141}$

The enactment of the War Powers Resolution in $1973^{142}$ was an attempt to limit the Commander in Chief powers by restoring the offensive/ defensive distinction central to maintaining the boundary line between war and peace. ${ }^{143}$ Section 2 of the Resolution defined a national emergency, which permits the Commander in Chief to introduce armed forces into hostilities, as arising only "by attack upon the United States, its territories or possessions, or its armed forces."144 However, Section 2, entitled "Purpose and Policy," is merely hortatory. ${ }^{145}$ The Resolution's main attempt to limit executive power is temporal and procedural. Congress tried to restrict the President's use of troops in hostile situations by placing a cap of sixty days on the period for which the President can deploy armed forces without congressional permission. ${ }^{146}$ Furthermore, Section 5(c) of the Resolution permits Congress to direct the President to remove the troops at any time by concurrent resolution. ${ }^{147}$

Three years later, Congress enacted the National Emergencies Act (NEA). ${ }^{148}$ The Act terminated all emergency authority ${ }^{149}$ based on the past presidential declarations of emergency. ${ }^{160}$ The future exercise of emergency power required the executive to follow certain procedures. ${ }^{161}$ In addition, Congress could terminate future emergency declarations by concurrent resolution. ${ }^{162}$ To assure congressional review of any executive invocation of emergency power, the NEA mandated that within six

141. A. SCHLESINGER, supra note 4.

142. Pub. L. No. 93-148, 87 Stat. 555 (1973) (codified at 50 U.S.C. $\S \S 1541-1548$ (1982).

143. See supra notes 21-27 and accompanying text (explaining role of offensive/defensive force distinction in liberal tradition of restrained emergency power); see also S. REP. No. 220 supra note 26 (war and peace in the American constitutional system are "separate and distinct," purpose of the bill is to restore that distinction; id. at 3 (citing Bickel for proposition that restoring the balance in war powers is "one of line-drawing, of separating one thing from another").

144. 50 U.S.C. § 1544(c) (1982).

145. Ely, Suppose Congress Wanted a War Powers Act that Worked, 88 CoLum. L. REv. 1379 (1988); Note, $A$ Defense of the War Powers Resolution, 93 YALE L.J. 1330, 1335-36 (1984).

146. 50 U.S.C. $\S 1545$ (b) (1982). The President could extend the authority for one thirty day period, after which it would automatically terminate.

147. Id. § 1545(c). But see INS v. Chadha, 462 U.S. 919 (1983) (holding such legislation unconstitutional).

148. Pub. L. No. 94-412, 90 Stat. 1255 (1976) (codified at 50 U.S.C. $\S 1601$ (1982).

149. Certain emergency powers, such as those exercised pursuant to the Trading With the Enemy Act, were exempted from the NEA's termination provisions. See infra note 154.

150. 50 U.S.C. $\S 1601$ (1982).

151. 50 U.S.C. $\$ 1621$ (1982) (President must declare national emergency and submit report to Congress explaining basis for declaration).

152. The initial drafts of the bill contained an automatic termination provision similar to that found in the War Powers Resolution. See, e.g., National Emergency Hearings, supra note 67, at 527. The President objected, however, and eventually a compromise was worked out providing for the legislative veto by concurrent resolution. See National Emergency Act Hearings on H.R. 3884 Before the Senate Comm. on Governmental Operations, 94th Cong. 2d Sess. 3, 17-18 (1976) (remarks of Sen. Church and Sen. Mathias on executive objections and ultimate compromise). 
months of the declaration of a national emergency, "each House of Congress shall meet" to consider and vote on terminating the emergency. ${ }^{153}$

Congress next addressed what had been the most fecund statutory source for the perpetual "emergency" regulation during the prior four decades: Section 5(b) of the Trading With the Enemy Act (TWEA). ${ }^{154}$ In 1977, Congress limited TWEA powers to actual wartime conditions, and enacted a new statute, the International Emergency Economic Powers Act (IEEPA), to constrain the executive's emergency authority. ${ }^{106}$ Procedurally, the IEEPA conditioned the President's emergency power on a declaration of national emergency, consultation with Congress and reporting to Congress every six months. In addition, Gongress could terminate this emergency authority by concurrent resolution. Substantively, IEEPA strictly defined a national emergency as "any unusual and extraordinary threat, which has its source in whole or substantial part outside the United States, to the national security, foreign policy or economy of the United States," and required that the President declare "a national emergency with respect to such threat." This requirement stemmed "from a recognition that emergencies are by their nature rare and brief, and are not to be equated with normal ongoing problems." ${ }^{186}$ Congress wanted to remedy a key problem with Section 5(b) of the TWEA: there were "no standards" and "no criteria at all" governing the invocation of emergency power. ${ }^{137}$

So far, less than two decades after Congress initiated these efforts, the success of these statutes in limiting executive emergency authority is dismal. These statutes lie in shambles, wrecked by presidential defiance, congressional acquiescence, and judicial undermining. Virtually all observers recognize the War Powers Resolution to have been a failure. No President has ever filed a report starting the 60 day clock running, despite repeated executive introduction of armed forces into hostile situations in Indo-China, Iran, Lebanon, Central America, Grenada, Libya, and most recently the Persian Gulf. ${ }^{158}$ Congress has challenged this noncompliance

153. 50 U.S.C. $\S 1622$ (b)(c) (1982). Congress was determined "to insure that the extraordinary powers which now reside in the hands of the Chief Executive . . . could be utilized only when emergencies exist, and then, only under safeguards provided by Congressional review." Hearings on H.R. 3884 , supra note 152, at 2, 18; see also S. REP. No. 1168, 94th Cong. 2d Sess. 2, 5 (1976).

154. 50 U.S.C. app. \$ 5(b). See generally Emergency Controls on International Economic Transactions: Hearings Before the Subcomm. on International Economic Policy \& Trade of the House Comm. on International Relations, 95th Cong., 1st Sess. (1977) (outlining broad uses of TWEA). The TWEA had been exempted from the operation of the National Emergencies Act to allow Congress time to study the particular problems raised by the TWEA statute more carefully. Pub. L. No. 95-223, Section 101(b) \& (c), reprinted at 50 U.S.C. app. \$5(b) note (extension and termination of national emergency powers under the Trading With the Enemy Act).

155. Pub. L. No. 95-223, 91 Stat. 1625 (1977) (codified at 50 U.S.C. Supp. V §§ 1701 et seq. (1982).

156. H. R. ReP. No. 459, 95th Cong., 1st Sess. 10 (1977).

157. H.R. ReP. No. 459, 95th Cong., 1st Sess. 7, 8 (1977) (quoting Professors Stanley D. Metzger and Adreas Lowenfeld).

158. Ely, supra note 145 , at 1381 \& n.8. 
only once, without a decisive result. ${ }^{160}$ The judiciary has refused to adjudicate claims challenging executive action as violative of the Resolution, most recently holding that a challenge by over 100 Congressmen to the armed presence in the Persian Gulf was non-justiciable. ${ }^{160}$ Senator Robert Byrd recently introduced legislation to amend the Resolution by repealing its most important operative measures, including the 60 day clock. ${ }^{161}$ That "amendment" appears motivated by a growing conviction that the Resolution is unworkable. As John Hart Ely put it, "[r]epeal is one way to increase compliance." 182

The NEA and IEEPA have not fared much better. The executive has now utilized IEEPA five times since 1979, and in only one instance-the sanctions against Iran imposed in 1979-could a "real" national emergency have been said to exist. Resort to emergency powers against Nicaragua, South Africa, Libya and Panama has been dubious at best. ${ }^{163}$ One commentator observes, "These uses suggest that the statute can and will be invoked whenever the President desires to draw on its broad powers, whether or not there is a genuine emergency."164 Moreover, when Congress failed to reauthorize the Export Administration Act in 1984, the President utilized IEEPA to declare a national emergency and continue the controls on exporters and importers. ${ }^{165}$ Again, whether IEEPA's "real emergency" requirement was met is doubtful. ${ }^{166}$

The NEA's procedural requirements for reporting and congressional oversight have simply not been followed by either the executive or Congress. The President has submitted declarations of national emergency that track the language of the statute and provide sparse details of the basis for the purported emergency. Every six months the executive submits pro forma reports to Congress. Congress is then mandated under the

159. The one occasion was the Lebanon crisis, when Congress negotiated a "compromise" with the Reagan Administration permitting troops to remain in Lebanon for 18 months. Id. at 1381; Glennon, supra note 128 , at 667 .

160. Lowry v. Reagan, 676 F. Supp. 333 (D.D.C. 1987); Crockett v. Reagan, 720 F.2d 1355 (D.C. Cir. 1983); Sanchez-Espinoza v. Reagan, 568 F. Supp. 596 (D.D.C. 1983), affd, 770 F.2d 202 (D.C. Cir. 1985).

161. 100th Cong., 2d Sess., S.J. Res. 323, Cong. Rec. S7167, S7169 (daily ed. June 6, 1988). Congressman Lee Hamilton has introduced similar legislation on the House side. H.R. J. Res. 601, 100th Cong. 2d Sess. (1988).

162. Ely, supra note 145 , at 1384 .

163. Carter, International Economic Sanctions, 75 CALIF. L. REv. 1159, 1235 (1987) (resorting to IEEPA against Nicaragua, South Africa and Libya seems questionable). See Exec. Order No. 12,513, 50 Fed. Reg. 18,629 (1985); Exec. Order No. 12,543, 51 Fed. Reg. 875 (1986); Exec. Order No. 12,544, 51 Fed. Reg. 1235 (1986); Exec. Order No. 12,532, 50 Fed. Reg. 36,861 (1985) (South Africa); Exec. Order No. 12,635, 53 Fed. Reg. 12,134 (1988) (Panama).

164. Carter, supra note 163 , at 1235; see also Koh, supra note 128 , at 1264-65. Congressman Bingham, the main sponsor of IEEPA, has stated that the invocation of emergency authority with respect to Nicaragua perverts the intention of Congress in enacting the IEEPA emergency standard. N.Y. Times, May 12, 1985, at E22, col. 3.

165. Exec. Order No. 12,470, March 30, 1984, 49 Fed. Reg. 13,099 (1984).

166. Harris \& Bialos, The Strange New World of United States Export Controls Under the International Emergency Economic Powers Act, 18 VAND. J. Transnat'L L. 71, 81-82 (1985). 
NEA to consider every six months whether to terminate the emergency. ${ }^{\mathbf{1 0 7}}$ Yet Congress has never considered whether to terminate any of these purported emergencies, despite their continuation for years. Instead of one generic emergency droning on and on without review, we now have a number of little but no less dubious emergencies-unchecked, unreviewed, and perfunctorily reported. This miraculous reform is what Congress spent six years of intensive investigation, hearings, debate, and legislative drafting to achieve. ${ }^{188}$

The judicial role in the demise of NEA and IEEPA as effective limitations on emergency power has been equally shameful. In a series of cases the federal courts have undermined the thrust of the reform effort. In Dames \& Moore v. Regan, ${ }^{168}$ Justice Rehnquist interpreted the IEEPA generously to allow the President to nullify pre-judgment attachments of Iranian assets pursuant to the Iranian Hostage settlement. The Court also held that Congress had implicitly approved of broad executive emergency power to act without specific statutory authorization to settle or suspend American claims against Iran. ${ }^{170}$

Two years after the Dames $\mathbb{E}$ Moore decision, the Court, in INS v. Chadha, struck down as unconstitutional a form of the legislative veto which provided a critical congressional check in the War Powers Resolution, NEA, and IEEPA. ${ }^{171}$ Congress responded to Chadha by amending the NEA to provide for termination of national emergencies by means of a joint resolution. ${ }^{172}$ The present statute thus requires two-thirds of both houses to terminate a national emergency, given the almost absolute certainty of a presidential veto of a joint resolution. The statute now provides for a termination procedure that would ordinarily be available if there were no NEA, a remarkable accomplishment given the energy spent on ensuring that Congress would have a mechanism to "assert its ultimate authority"173 over emergency power.

167. NEA requires that "Not later than six months after a national emergency is declared, and not later than the end of each six-month period thereafter that such emergency continues, each House of Congress shall meet to consider a vote on a joint resolution to determine whether that emergency shall be terminated. 50 U.S.C. $\$ 1622$ (b) (1982) (emphasis added). It further provides that "a joint resolution to terminate a national emergency shall be referred to the appropriate committee" and "shall be" reported out of committee and acted upon by both houses. Id. $\$ 1622$ (c).

168. One commentator has noted that the NEA and IEEPA's procedural requirements "remain at face value, little more than traps for the unwary Presidential draftsman. . . . One must question whether IEEPA has imposed any appreciable limitation upon the actual exercise of Presidential power under emergency conditions." Malloy, The Iran Crisis: Law Under Pressure, 1984 WIS. INT'L L.J. 15, 28, 27.

169. 453 U.S. 654 (1981).

170. For a critique of Dames $\&$ Moore, see Koh, supra note 128, at 1310-11.

171. 462 U.S. 919 (1983). The War Powers Resolution contained both a legislative veto, and an automatic termination provision that survives Chadha. Compare 50 U.S.C. $\S 1545$ (b) with $\$ 154(\mathrm{c})$.

172. Act of Aug. 16, 1985, Pub. L. No. $99-93 \S 801$, 99 Stat. 448 (1985). Unlike a concurrent resolution, a joint resolution is subject to executive veto and therefore survives the Chadha decision.

173. 122 CoNG. REC. 28227 (1976) (statement of Senators Church and Mathias). 
A year after the Chadha decision, the Court in Regan v. Wald ${ }^{174}$ again affirmed executive emergency power, this time reading the grandfather provision of IEEPA to permit the continuation of the old embargoes against Cuba, North Vietnam, China, and several other nations. The Court's broad interpretation disregarded clear congressional intent. ${ }^{175}$ The implications of the Court's opinion are broader than its actual holding. As Professor Koh notes, the combination of Dames \& Moore, Regan v. Wald, and the Court's more recent decision in Japan Whaling Ass'n $v$. American Cetacean Soc'y, ${ }^{176}$ "have provided the lower courts with a theory of statutory construction that has legitimated broad exercises of emergency economic powers under claims of delegated authority."177

Finally, a Federal District Court in 1986 ruled that whether Nicaragua posed a sufficient threat to warrant the President's declaration of emergency pursuant to the IEEPA presented a non-justiciable question. ${ }^{178}$ The Court of Appeals affirmed on other grounds, addressing inter alia, Congress' failure to meet to consider a vote to terminate the emergency. Reading the "shall meet to consider a vote" provision as only giving those who want to vote an opportunity to do so, the court in essence held that there was no legal remedy for a congressional failure to comply with the statute. ${ }^{179}$

The combined impact of these decisions is the following: (1) executive emergency power under IEEPA must be broadly interpreted; (2) the attempt to limit the circumstances under which the President can exercise emergency powers by defining emergency is judicially unenforceable; (3) Congress' only mechanism for terminating an emergency the President wants to continue is to pass a joint resolution with a two-thirds majority, given the virtual certainty of a Presidential veto; ${ }^{180}$ and (4) whatever pro-

174. 468 U.S. 222 (1984).

175. Regan v. Wald, 468 U.S. 222, 250-57 (Blackman, J., dissenting). 468 U.S. at 262 (Powell, J., dissenting). Commentators have generally viewed the Court as distorting congressional intent. Note, Executive Authority: Restriction of Travel to Cuba, 26 HARv. INT'L L.J. 217, 224 (1985) (questioning Court's view of congressional intent); Note, Executive Authority-Broad Presidential Embargo Powers Preserved Despite Statutory Construction, 20 TEx. INT'L L.J. 401, 408 (1985) (Court replaced congressional views with its own); Note, The President's International Emergency Economic Powers After Regan v. Wald: An Unchecked Proliferation of Authority, 12 SyRACuSE INT'L L.J. 125, 128 (1985) (decision appears to contravene clear legislative intent of IEEPA); Note, The Right to Travel \& Presidential Emergency Authority: The Supreme Court Lowers the Standard of Review in Regan v. Wald, 44 Al.B. L. REv. 1001, 1002 (1985) (Court found executive power "despite clear expressions of legislative intent to the contrary").

176. 478 U.S. 221 (1986) (permitting executive discretion in imposing sanctions against nations that violate whaling ban, despite language and legislative history that seemingly deny such discretion).

177. Koh, supra note 128, at 1305-06 \& n.232.

178. Beacon Products Corp. v. Reagan, 633 F. Supp. 1191, 1194-95 (D. Mass. 1986); affd on other grounds, 814 F.2d 1 (91st Cir. 1987).

179. Beacon Products Corp. v. Reagan, 814 F.2d 1, 4-5 (1st Cir. 1987).

180. The Tenth Circuit's decision in United States v. Bishop, 555 F.2d 776 (10th Cir. 1977), one of the few cases to provide any review of the exercise of emergency power, clearly understood the implications of these judicial decisions. Writing in 1977, prior to Chadha, Judge Breintenstein noted: "If President Ford was correct in his position that the provision of the National Emergencies Act for termination of an emergency by act of Congress is unconstitutional and, if the government is correct in 
cedures Congress has established to review these emergencies are legally unenforceable in the courts. It is hard to discern any progress from the post-war era of drastic abuses that Congress wanted to end.

\section{Recent Expansion of Executive Emergency Authority}

In addition to dismantling the reform statutes of the 1970s, Congress and the President have been busily creating new broad and undefined delegations of emergency authority. The "drug crisis," most recently described by President Bush as equivalent to "an invading army,"181 led Gongress to create "emergency" exceptions to the deeply rooted tradition prohibiting the use of the military to enforce civilian laws. ${ }^{182}$ Throughout the past decade, Congress has continually broadened those "emergency" exceptions. ${ }^{183}$ In April 1986, President Reagan issued a secret directive authorizing the use of 160 United States Army troops as logistical support for the effort to uproot the drug trade in Bolivia, because the "emergency circumstance" of a serious threat to national security was present. ${ }^{184}$

Two additional measures, which thus far have not been enacted, illustrate the current mood in Congress. Amendments offered by Representatives Bennett and Hunter would have allowed the military to participate in searches outside the United States, and seizures and arrests within the territory of the United States. Though destructive of the principle that the military not become involved in civilian law enforcement, ${ }^{185}$ these amendments passed the House 359 to 52 and 237 to 177 , respectively. ${ }^{186}$ While finding some support in the Senate, both amendments were ultimately de-

the position which it takes in the instant case that the judiciary may not terminate an emergency, the awesome power of the President to declare an emergency and thereby activate 470 federal laws is unfettered." Id. at 776-77.

181. Then President-elect Bush recently turned to the oft-used metaphor: "We are at war. Drugs are a terrifying, insidious enemy; they challenge almost every aspect of American public policy-the law, our national security, our public health. And the threat they pose reaches deep into our national soul." N.Y. Times, Jan. 13, 1989, at 10, col. 1.

182. 10 U.S.C. $\$ \S 371-378$ (1982). See Review of the Administration's Drug Interdiction Efforts: Hearings Before a Subcomm. of the House Comm. on Government Operations, 98th Cong., 1st Sess. 9-10 (1983) (statement of Sen. Lawton Chiles); Note, Fourth Amendment and Posse Comitatus Act Restrictions on Military Involvement in Citril Law Enforcement, 54 Geo. WasH. L. Rev. 404, 417 (1986).

183. For example, in authorizing the use of Federal law enforcement officials and military personnel and equipment to fight drug trafficking or illegal immigration outside of the United States, Congress in 1986 broadened the emergency circumstances in which such activities would be permitted. 10 U.S.C. $\$ 374(B)(3)$ (Supp. 1987) (Note on 1986 amendment). Congress also permitted the interception of vessels and aircraft outside United States territory by military personnel in emergency circumstances. 10 U.S.C. \$ 374(B) (Supp. 1987).

184. Have We Really Gone to the Source, L.A. Daily J., July $21,1986, \S 1$, at 4 col. 2. (reprinted from Washington Post).

185. H.R. ReP. No. 51, 97th Cong., 1st Sess. reprinted in 1981 U.S. Code ConG. \& ADMIN. News 1781, 1799-80 (dissenting views of John Conyers).

186. 132 ConG. REc. H6660-6688 (daily ed. Sept. 11, 1986). 
feated, after having been characterized by Senator Sam Nunn as representing the largest peacetime grant of power to the President in history. ${ }^{187}$

The perception of a crisis in Central America has also led Congress to relax controls on the use of the National Guard. Until 1986, only in time of national emergency or war could the President deploy a state's National Guard units outside the United States without the governor of the state's approval. Non-emergency National Guard training exercises abroad required the governor's consent. ${ }^{188}$ In 1986, Congress enacted the Montgomery Amendment to prohibit governors from withholding their consent to the deployment of National Guard units outside the United States because of an objection to the location, purpose, type or schedule of such assignment. ${ }^{189}$ The immediate purpose was to prohibit the governors from exercising a veto on the Administration's use of the National Guard to conduct exercises in Honduras. What Congress' reaction did, however, was to eviscerate the division between the executive's unfettered emergency power to deploy the National Guard abroad and the executive's non-emergency power to send those units abroad for training, the latter power formerly requiring the consent of the state's governor. ${ }^{190}$

Other newly discovered crises leading to the promulgation of emergency plans and regulations are posed by immigration and terrorism. These two

187. 132 Cong. Rec. S13975, S13978, S14009 (daily ed. Sept. 27, 1986).

188. 10 U.S.C. $\S \S 672,673$ (1982). Apart from declared national emergencies, there were a few other specifically defined conditions under which the President could order National Guard members to active federal duty. 10 U.S.C. $\S \S 673(\mathrm{a})$,(b) (1982).

189. Act of Nov. 14, 1986, Pub. L. No. 99-661 § 522, (codified at 10 U.S.C. $\S 672(f)$ (Supp. 1987)).

190. Governors Rudy Perpich of Minnesota, and Michael Dukakis of Massachusetts promptly challenged the constitutionality of the Montgomery Amendment. The First Circuit dismissed Dukakis' lawsuit. Dukakis v. U.S. Dep't of Defense, 859 F.2d 1066 (1st Gir. 1988). The Eighth Circuit, however, upheld Perpich's challenge. Perpich v. U.S. Dept. of Defense, No. 87-5345 (8th Cir. Dec. 6, 1988) reh'g en banc granted (8th Cir. Jan. 11, 1989) (WESTLAW Allfeds Library).

The reasoning of Perpich v. U.S. Dept. of Defense is instructive on just how muddy the emergency/ non-emergency distinction has become. The Eighth Circuit understood that the key constitutional defect of the Montgomery Amendment was its evisceration of the line between executive emergency authority and non-emergency power requiring the governor's consent. The court attempted to respond by requiring "that before the federal government can exercise its army power to supersede the reserved state authority over the militia, its actions must be motivated by a state of events which amounts to a "national exigency." "Id.

The Eighth Circuit decision in Perpich was by a divided panel, and it is unclear whether it will survive appeal. Indeed the Eighth Circuit has vacated the panel opinion pending en banc review. Yet even the panel's courageous opinion illustrates the rapid demise of the emergency/non-emergency dichotomy. Apparently worried that its opinion would be attacked as interfering with federal foreign affairs power, the majority noted that:

the power to determine the existence of such circumstances [a "national exigency" or "specific

threat to national security"] belongs only to Congress or the President. Once this power is exercised, the substance of the determination cannot be challenged by the states or by individual National Guard members sent into federal service. Such a challenge would involve a central political question.

In short, had Congress conditioned executive power to train National Guard units abroad without the governor's consent upon a declaration of "national emergency," then the executive's authority to use the National Guard would be unreviewable. This is the bright line drawn by the only court willing to engage in any line-drawing. 
emergencies tend to be linked, because the threat from abroad seems personified by the presence of aliens living in our midst. A recent draft Executive Order allegedly contained provisions for "alien control," the "detention of enemy aliens," and the seizure of their property. ${ }^{101}$ Rex-84-Bravo, a national simulation staged by FEMA in April 1984, involved the activation of "emergency legislation" and "assumption of emergency powers" including a "roundup of Central American refugees."102

The Iran-Contra affair also illustrated the danger of emergency power run amok. Iran-Contra exposed a secret, parallel government, developed outside of normal constitutional processes to respond to perceived national security crises. Secret institutions were created to carry out United States foreign policy, including "off the shelf" companies, ${ }^{193}$ capable of conducting operations usually undertaken by governmental institutions. The resurgent reliance on agencies, "companies," and "enterprises" to conduct "sensitive" national security operations, shielded from the democratic process, undermines executive accountability and blurs the line between democratic and authoritarian government. ${ }^{194}$

During his last months in office, President Reagan issued an Executive Order outlining his wide ranging emergency powers: to use military personnel in civilian law enforcement, to regulate aliens, to impose wage and salary controls, to control civilian transportation, to acquire and lease

191. B. BRADlEE, supra note 1, at 132; Reagan Advisors Ran Secret Government, supra note 1. An internal FEMA memo outlining the martial law aspects of the plan was described by the Herald as somewhat resembling a paper FEMA Director Louis Gruffrida wrote as a student at the Army War College, a paper which discussed the most efficient way to remove an estimated 500,000 militant "American Negroes by placing them in internment camps in case of a black revolt." Miami Herald, July 19, 1987 at $17 \mathrm{a}$, col. 1; see also B. BradLEE, supra note 1, at 133-35.

192. Reagan Advisors Ran Secret Government, supra note 1. The Immigration and Naturalization Service (INS) has also developed contingency plans to deal with "Alien Terrorists and Undesirables." See Investigative Division of INS, Alien Terrorists and Undesirables: A Contingency Plan (1986) (copy on file with author). The Office of the General Counsel recognized in 1986 that in an emergency the INS may need to "place strict control on certain alien nationals or classes of aliens," requiring the "issuance of emergency regulations." Id. Memo of April 23, 1986 from Office of General Counsel. During the Iranian hostage crisis, the Attorney General actually promulgated a regulation requiring all Iranian students to report to a local INS office, a regulation upheld by the D.C. Circuit. Narenji v. Civiletti, 617 F.2d 745 (D.C. Cir. 1979), cert. denied, 446 U.S. 957 (1980). The Circuit Court refused to "pass judgment on the decisions of the President in the field of foreign policy", and thereby accepted the challenged regulation as rational. 617 F.2d at 748 . Only the four circuit judges dissenting from the refusal to rehear the case en banc suggested a traditional liberal analysis, under which the case presented a conflict between necessity and the rule of law. 617 F.2d at 754-55. Though in dictum, the Supreme Court also recently noted the constitutionality of detaining aliens during a time of war. United States v. Salerno, 107 S. Ct. 2097, 2102 (1987).

193. Iran-Contra Report, supra note 80, at 413 (describing Col. North's testimony).

194. See generally B. Moyers, The Secret Government, The Constirution in CRisis (1988) (describing undermining of democracy by development of secret government). The Miami Herald exposure of the FEMA plan reported FEMA's activities against a background of the operation by some of President Reagan's top advisors of a "virtual parallel government," "almost from the day Reagan took office." Reagan Advisors Ran Secret Government, supra note 1. In an ironically secret assessment of these activities, Arthur Liman, lead counsel for the Senate Iran-Contra Committee, called it "a secret government within a government." Id. Sources told The Herald that the arrangement permitted Reagan administration officials to claim that they were not involved in controversial or illegal activities. Id. 
property, and to take control of civilian nuclear plants. ${ }^{195}$ As usual, the Order defines the requisite emergency circumstance broadly: "any occurrence including natural disaster, military attack, technological emergency, or other emergency, that seriously degrades or seriously threatens the national security of the United States." ${ }^{196}$ Not only have the reform statutes failed, but emergency authority continues to escalate, unbounded by serious limitations.

\section{Restoring and Ultimately Transforming Liberal Constitutional Limitations: NeW Possibilities for UnIted States Foreign Policy}

\section{A. The New Reformists}

A controversy now rages as to the causes of and the lessons to be learned from the failure of 1970 s reforms. One perspective views the proposals to curb emergency power as fundamentally misguided. According to this outlook, the magnitude of the threat facing the country requires a strong President and a cooperative Congress supportive of executive initiatives. For these "interventionists," the lesson of the Vietnam War and the Iran-Contra affair is not the need for more congressional checks on executive power, but rather the removal of such restraints. The escalation of the Iran-Contra affair, for example, is ascribed to Congress' attempts to interfere with executive conduct of foreign policy. ${ }^{197}$ Prominent interventionists comment that the constraints imposed by Congress "have undermined rather than enhanced deterrence," and "fueled potentially catastrophic constitutional confrontations with the Presidency",;188 Vietnam and IranGontra require reform to "restore the Presidency to the position it held just a few administrations ago."189

Powerful adherents from both major parties share the view that conflict and confrontation between the President and Congress must be reduced, and that the constitutional separation of powers must be weakened. Lloyd Cutler, President Carter's White House Counsel; Douglass Dillon, a distinguished public servant in the Eisenhower and Kennedy Administration; and Senator Nancy Kassebaum joined other luminaries in establishing the Committee on the Constitutional System in 1982. The frustrations Cutler and others felt during the Carter Administration inspired their renewed

195. Exec. Order 12,656, 53 Fed. Reg. 47,491 (1988).

196. Id. $\S 101$. Executives of the nuclear industry were dismayed that the order did not make clear what political, technological or military factors would be considered a national security emergency. N.Y. Times, Nov. 22, 1988 at B6, col. 1.

197. J. Moore, Government UNDER LAw AND CoverT Operations, (1980) reprinted in Iran-Contra Report, supra note 80, at pp. 614, 617 (minority report). The Minority Report stated that a number of the mistakes of the Iran-Contra Affair resulted directly from the "political guerilla warfare between the legislative and executive branches." Id. at $437,439$.

198. Id.

199. Iran-Contra Report, supra note 80 , at 449,585 (minority report). 
interest in a more parliamentary system of government as a means of restoring executive authority to lead the country and act decisively. The Committee's Basic Policy Statement asserted, "The checks and balances inspired by the experience of the Eighteenth century have led repeatedly, in the Twentieth Century, to governmental stalemate and deadlock, to indecision and inaction in the face of urgent problems." ${ }^{200}$ Echoing Senator Fulbright's sentiments during the early 1960s, ${ }^{201}$ Dillon asked whether modern America "can continue to afford the luxury of the separation of power." 202

However, the present quest to restore American dominance through a stronger executive ${ }^{203}$ is quixotic. The decline of global power is less a function of constitutional structure than of economic and political change: namely, the growth of Soviet military power, the economic competition from other capitalist countries, and the rise of revolutionary nationalism in the Third World. As the Soviets discovered in Afghanistan, the defeat of a strong nationalist movement is difficult even if a superpower's legal structure facilitates the flexibility necessary for the pursuit of an aggressive foreign policy. Recent theorists argue that the decline of American power can be linked to the costs of defending and extending our power throughout the world. ${ }^{204}$ The escalation of intervention around the world will only hasten the long-term decline.

The interventionist vision should also be rejected because it results in the chronic abuse of executive power. The interventionist solution essentially removes the tension between the rule of law and the necessities of a strong foreign policy by sacrificing the former ideal. Even if it were possible for strong executive action to restore American power, is it worth the diminution in democratic government? The domestic order cannot be insulated from the international arena; eviscerating legal restraints on the executive's conduct of foreign policy inevitably will lead to undermining domestic civil liberties. ${ }^{205} \mathrm{McCarthyism}$ was directly related to the rise of broad emergency power to fight the perceived Communist threat

200. A. Schlesinger, The Cycles of American History 302-03 (1986) (quoting Committee on the Constitutional System, Basic Policy Statement: After Two Centuries: Our Eighteenth Gentury Constitution in Today's Complex World 3 (1983)).

201. See supra note 69.

202. Dillon, The Challenge of Modern Governance, in Reforming AMERICAN Government: The Bicentennial Papers on the Committee on the Constitutional System 28-29 (D. Robinson ed. 1985). Indeed, Fulbright now supports the move toward a more parliamentary system to provide for more cooperation and less conflict in the making of foreign policy. J. FuLBRIGHT, THE PRICE OF EMPIRE 60-75 (1989).

203. A. Schlesinger, supra note 200, at 302-03 (1986).

204. D. Calleo, Beyond American Hegemony (1987); R. Gilpin, War \& Change in World Politics 156-77 (1981); P. Kennedy, The Rise \& Fall of the Great Powers (1987); M. Olson, The Rise and Decline of Nations (1982); see also Koh, supra note 128, at 1293 n. 170 .

205. See supra note 4; see also S. REP. No. 220, 93rd Cong. 8 (1973) (when checks and balances are disrupted in foreign policy, "all other [areas of public policy] are affected, and so also are the basic rights of the citizen"). 
abroad. ${ }^{206}$ The sense of urgency that led Congress to permit "emergency" use of the military in civilian law enforcement to combat drug smugglers has led to a relaxation of Fourth Amendment restraints on the war on drugs at home. ${ }^{20 z}$

\section{B. Current Attempts to Revive Restraints on the Executive}

Supporters of the reformist initiatives of the 1970s have, of course, a different explanation for their failure. Their views can be grouped into two camps, labelled by Kenneth Sharpe as the "aberrationists" and the "legalists." 208 The aberrationists blame the failure to comply with the Constitution or law on individual mistakes. The majority report of the Iran-Contra Committees, for example, argues, "[T]he Iran-Contra Affair resulted from the failure of individuals to observe the law, not from deficiencies in existing law or in our system of governance."209

Yet while any one scandal can always be blamed on individual mistakes, the inability of the reform statues to check executive abuse in a wide variety of emergency power contexts ${ }^{210}$ simply cannot be the product of individual dishonesty, corruption, ambition or stupidity. As Professor Harold Koh perceptively comments, the Iran-Contra affair represented not simply an aberration, "but deeper systemic flaws in the current legal structure of our foreign policymaking process."211

The legalist response to the reformist failure proposes stronger and more comprehensive reforms designed to restore the dichotomy between emergency and normal executive power, war and peace, and ultimately constitutional versus unconstitutional government. Some recent proposals are process-oriented. Professor Koh advocates a new national security "charter," which would "seek to alter recurrent patterns of executive behavior by restructuring the institutional attributes" that contribute to executive excesses. ${ }^{212}$ Professor Koh's design would encourage Congress and the judiciary to become involved in foreign policy issues. Other, more specific, process-oriented reforms would provide for judicial review of execu-

206. See, e.g., Douglas, The Black Silence of Fear, N.Y. Times, Jan. 13, 1952, § 6 (Magazine) at 7. Similarly, the Executive's abuse of power in Vietnam encouraged President Nixon to engage in unlawful conduct to thwart the domestic anti-war movement and ultimately helped create the environment in which the Watergate scandal was launched. T. SoRENSON, WATchmen IN THE Night 18-19 (1975); Bernstein, The Road to Watergate and Beyond: The Growth and Abuse of Executive Authority Since 1940, 40 Law \& Contemp. Probs. 58 (1976).

207. See Skinner v. Railway Labor Executive's Association, No. 87-1555 (U.S., March 21, 1989) (WESTLAW, Allfeds Library) (Marshall, J., dissenting); National Treasury Employees Union v. Von Raab, No. 87-1879 (U.S., March 21, 1989) (WESTLAW, Allfeds Library).

208. Sharpe, The Real Cause of Irangate, 68 Foreign Por'y 19, 34 (1987).

209. Iran-Contra Report, supra note 80 , at 423 . The minority report agreed "that the underlying cause of the Iran-Contra Affair had to do with people rather than with laws." Id. at 583 (minority report).

210. See supra Parts IV, V.

211. Koh, supra note 128 , at 1257.

212. Id. at 1323. 
tive use of force pursuant to the War Powers Resolution, ${ }^{213}$ and tighten the requirements for executive notification to Congress of anticipated covert action. ${ }^{214}$ In addition, some commentators urge the imposition of stricter substantive limits on the President's emergency powers, such as providing a stricter definition of what constitutes a national emergency, ${ }^{215}$ prohibiting certain types of covert activity, ${ }^{216}$ or restricting the situations in which the President can use force against another nation. ${ }^{217}$ In the current political context none of these process-oriented or substantive proposals are likely to be adopted.

\section{Beyond Legalism: The Connection Between Substantive Policy and Legal Reform}

The legalist proposals, while recognizing a systemic pattern, still fail to address the basic problem leading to both the events of the Iran-Contra affair and the drafting of the FEMA plan. The line separating executive emergency power and normal constitutional government has become blurred, not only because of legal or institutional failure, but primarily because of an aggressive United States assertion of power in the international arena.

Old lessons have to be constantly relearned. The debate over the IranContra scandal narrowly focused on such issues as what the President knew, whether the law was violated, and whether new legislation is needed. Commentators have generally ignored the causal connection between the persistent failure of the executive to heed constitutional or legal limitations in its efforts to overthrow the Nicaraguan government and an

213. Ely, supra note 145. Ratner \& Cole, The Force of Law: Judicial Enforcement of the War Powers Resolution, 17 LOY. L.A.L. REv. 715 (1984). These commentators suggest that the judiciary not employ such mechanisms as the political question doctrine or standing to avoid ruling on whether the executive has complied with the War Powers resolution.

214. IRAN-CONTRA REPORT, supra note 80 , at 423.

215. Relyea, Reconsidering the National Emergencies Act: Its Evolution, Implementation and Deficiencies in 5 The Presidency and National Security Policy 274, 317-18 (G. Hoxie ed. 1984) (urging definition of conditions that constitute a "national emergency").

216. H. R. REP. No. 833, 94th Cong., 2d Sess. 2 (1976). The Senate Select Committee on Intelligence recommended prohibiting various classes of covert action such as "efforts to subvert democratic governments" and assassinations of foreign officials. Church Comm. Report supra note 90. S. REP. No. 755, Book I, 94th Cong. 2d Sess. 448 (1976); see also Lobel, supra note 26 (suggesting prohibiting executive sponsored paramilitary action undertaken without congressional approval).

217. See Franck, After the Fall, The New Procedure for Congressional Control Over the War Power, 71 AM. J. INT'L L. 605, 639 (1977) (restricting Presidential wars to situations of actual or imminent attack on U.S. territory, on the armed forces, and perhaps on civilians abroad, which would be enforced by the "prior restraint" that no funds may be expended for armed forces involved in hostilities except in these situations or when explicitly authorized by Congress); Glennon, The War Powers Resolution Ten Years Later: More Politics than Law, 78 AM. J. INT'L L. 571, 580 (1984). See Congressman DeFazio's proposed amendments, H.R. J. Res. 462, 100th Cong. $2 d$ Sess. $\S 3, \S 7$ (1988) (limiting situations of use of force and providing for judicial enforcement); Ely, supra note 143, at 1393 n.45 (describing Defazio amendments); see also Note, Realism, Liberalism and the War Powers Resolution, 102 HaRv. L. REv. 637, 653 (1982) (proposing that one alternative "representative of liberal thinking" is to reinstate the Senate's original substantive restraints). 
aggressive view of American power in the world. ${ }^{\mathbf{2 1 8}}$ Yet two decades ago, the Vietnam War vividly brought this lesson into focus.

As the war in Vietnam dragged on, thoughtful commentators began to question whether our constitutional assumptions could withstand the quest for empire. The doubts that had earlier appeared in the 1890's as to whether the Constitution could function "for a conquering nation"219 reappeared forcefully in the 1960s. Henry Steele Commager wrote that the "abuse of power by Presidents is a reflection, and perhaps a consequence, of abuse of power by the American . . . nation."220 In the long run, "abuse of executive power cannot be separated from abuse of national power. If we subvert world order and destroy world peace, we must inevitably subvert and destroy our own political institutions first." 221 The answer to abuse of executive power, was and still is, neither the removal of evil people, nor the reform of insufficient laws, but rather the dissipation of the "forces, motives and fears which underlie the exercise and the rationale of excessive presidential power."

The Vietnam War also led William Fulbright to re-evaluate dramatically his earlier views on empowering the Presidency. The failure in Vietnam provided an occasion to rethink the messianic anti-communism that drove the United States to unilaterally intervene anywhere in the world in the name of national security. For Fulbright the conflict was clear. If "America is to become an empire, there is very little chance that it can avoid becoming a virtual dictatorship as well."223

While better Presidents, advisors, and laws are both necessary and significant in curbing executive power, the failure of legal reforms reflects the nation's failure to dramatically alter its substantive world view. ${ }^{24}$ The procedural constraints the Constitution places on executive action reflect a substantive vision of America's place and role in the world. That vision stemmed from a militarily weak America, whose leaders sought to avoid,

218. See, e.g., Said, Representing the Colonized: Anthropology's Interlocutors 15 CRITICAL INQUIRY 205, 216 (1989) (little of immense media and opinion deluge on Iran-Contra affair paid any attention to fact that our Iranian and Central American policies are nakedly imperialist policies). For example, the Iran-Contra report paid no attention to the connection between the substance of the Reagan policy against Nicaragua and the unconstitutional means used to implement that policy. For two exceptions, see Scharp, supra note 208; Krautheimer, The Price of Power, New Republic, Feb. 9,1987 , at 23 .

219. See supra note 60 and accompanying text.

220. H. CoMmager, supta note 53 , at 57 .

221. Id.

222. Id. at 57. Presidential adviser and well known historian Arthur Schlesinger arrived at a similar conclusion in The Imperial Presidency, finding it difficult to reconcile the traditional view of separation of powers with post-War American foreign policy. The "Constitution could not easily sustain the weight of the indiscriminate globalism to which the Korean War gave birth." "This vision of the American role in the world," Schlesinger wrote, "unbalanced and overwhelmed the Constitution." A. Schlesinger, supra note 4, at 168-69. For Schlesinger, the Johnson Administration's, theory of "[d]efensive war had always been the theory of empire." Id.

223. 115 Cong. REc. 16618 (June 19, 1969).

224. Sharpe, supra note 208. 
as much as possible, involvement in European wars. ${ }^{225}$ That vision no longer comports with our role as the dominant world power.

Our relative power to shape world affairs has declined since the 1950s; a spate of recent scholarship suggests that the decline will continue. ${ }^{228}$ The continued quest for dominance will therefore surely bring with it continued crisis. The more forcefully America strives to maintain hegemony, the stronger the perception of crisis will be. The policy of hegemonic maintenance is simply inconsistent with reinvigorating the carefully balanced dualities encapsulated in our constitutional assumptions. ${ }^{\mathbf{2 2 7}}$

An essential prerequisite to any legalist revival of the liberal model is the dissipation of the sense of permanent crisis which underlies the muddying of the emergency/non-emergency distinction. ${ }^{228}$ Revitalizing the liberal legal paradigm requires a substantive redefinition of United States national security that does not necessitate the present imperial responsibility which inevitably leads to continued crisis.

Such a transformation would involve several related components. First, the pervasive anti-communism that has been so central to the foreign policy of each of the past eight administrations must be discarded. Second, the United States must relinquish the prevailing assumption that our national security requires the prevention or overthrow of leftist revolutionary governments throughout the world. ${ }^{229}$ The breakup of the monolithic communist world, which began with the Chinese-Soviet rupture of the early 1960's and has proceeded apace more recently under Gorbachev's Soviet Union, should force a re-evaluation of the view that any leftist revolution automatically leads to a Soviet client state. ${ }^{230}$ Third, in response to Gorbachev's initiatives, we must move to end the cold war and substitute cooperation for containment in our relations with the Soviets. ${ }^{231}$

225. See supra notes $52-58$ and accompanying text.

226. See supra note 204.

227. See supra notes 197-199 and accompanying text.

228. As the Senate Foreign Relations Committee recognized in proposing war powers legislation in 1973, the bill would not restore checks and balances without substantive changes in American foreign policy: "If the country is to be continually at war, or in crisis, or on the verge of war, or in small-scale, partial or surrogate war, the force of events must lead inevitably toward executive domination despite any legislative roadblocks that may be placed in the executive's way." S. REP. No. 220, 93rd Cong, 1st Sess. 20 (1973).

229. Sharpe, supra note 208, at 41 ; see also W. Williams, The Tragedy of American DiPLOMACY 212 (1959) (essence of different foreign policy would be open door for revolutions).

230. The New York Times terms recent changes in the communist world "stunning." More Ice Keeps Breaking, N.Y. Times, Apr. 7, 1988, at 22, col. 1 (editorial). Those changes have occurred in both domestic and foreign policy. The recent actual or promised withdrawals of Soviet troops from Afghanistan, Cuban troops from Angola, and Vietnamese troops from Cambodia seem to signal a different attitude about the willingness of these states to intervene militarily to support revolutions. Id. (calling for end to United States policy in Cambodia to "aid[] or tolerate[] any faction that resisted a Soviet-supported occupation"). Internally the democratic changes recently introduced in the Soviet Union, Hungary and Poland are simply the most dramatic aspects of an increasing decentralization and experimentation in the communist world.

231. Many commentators from various political spectrums have recently called for ending the cold war. Barnet, Fear of Soviet Changes Sells America Short, L.A. Times, Dec. 19, 1988 \&I at 5, col. 4; Cohen, Will We End The Cold War? The Next President's Historic Opportunity, 245 Nation 293 
Finally, a different foreign policy requires recognizing and adapting to the economic and political interdependence of nation-states, requiring, in Mikhail Gorbachev's words, "the need to devise a fundamentally new machinery for the functioning of the world economy."232 This would require increased United States reliance on multilateral political, economic, and judicial institutions to resolve international problems.

These changes are not a panacea; problems with other nations, terrorists, drug smugglers, and an influx of aliens would continue to exist. A transformed foreign policy would, however, facilitate our ability to address the causes of these problems and thereby alleviate the sense of crisis pervading the nation. ${ }^{233}$

Legalist proposals would be less likely to be perceived as unrealistic if the United States were to modify basic assumptions underlying foreign policy. While any of the legal reforms outlined earlier would represent improvements over the present situation, ${ }^{234}$ the most effective reform approach would involve revitalizing the liberal model contained in our original constitutional framework. This approach would not only provide for judicial or congressional review of executive emergency action, but also substantively restrict executive constitutional emergency power. The only emergency power clearly provided under the Constitution is that of defending against armed attacks by other nations. In other situations, the executive should be forced to seek specific congressional authorization prior to acting, or to act unconstitutionally in those rare emergencies

(1988). Cohen, Centrists Lack the Guts to Respond to Gorbached, N.Y. Times, Sept. 19, 1988, at A23, col. 2; Parks, To Clear Cold War Leftovers, L.A. Times, Oct. 2, 1988, § V, at 1, col. 1; Rosenthal, Gorbachev in Motion, N.Y. Times, Dec. 11, 1988, at E1, col. 1; Rostow, Five Great Goals for the Next Generation, Wall Street Journal, Sept. 6, 1988, at 30, col. 3; Ullman, Ending the Cold War, 72 Foreign POL'y 130 (1988).

232. Gorbachev's Olive Branch, Wash. Post., Dec. 11, 1988, at K1, col. 1.

233. Various commentators have argued that charting a new cooperative direction in U.S. foreign policy would reverse the disproportionate growth of the military expenditures and the over-extension of U.S. military power that has been a major factor in the decline of U.S. economic strength. P. KENNEDY, supra note 204, 514-534; Shulman, The Superpowers: Dance of the Dinosaurs, 66 FoREIGN AFF. 494, 508 (1988).

Recognizing and tolerating nationalism in the middle east would in the long run alleviate the terrorism problem in that the United States would not be perceived as the main defender of the status quo. Friedman, Camp David Accords 10 Years Later: Carter Ponders Why It Turned Sour, N.Y. Times, March 26, 1989, § I, at 4, col. 1 (former President Carter believes committing ourselves to peace and Palestinian rights will dissipate hatred against United States). Relinquishing our reliance on anti-communism should lead to a reluctance to continue to ignore the drug activities of some of our "friends" in Latin and South America in return for their support against communism. See e.g., Berke, Foreign Policy Said to Hinder Drug War, N.Y. Times, April 14, 1989 at 5, col. 4 (Senate Report concludes that we tolerated drug activities because we did not want to crack down on anti-communists we supported). Focusing on the economic problems of Latin America in a multilateral fashion instead of supporting corrupt military run governments or counter-revolutionary groups would, in all likelihood, reduce the flow of immigrants from such nations as EI Salvador, Guatemala, Nicaragua and Haiti. See generally Cohen, Will We End the Cold War?, supra note 231, at 312-13 (discussing implications of post-cold war foreign policy for solving current problems). While we would still face serious problems, those problems might be more manageable without a "crisis" or "war" imagery.

234. See supra notes 211-17. 
which threaten the nation's existence and for which response is needed before Congress can meet. ${ }^{235}$

This approach could be imposed on a variety of emergency contexts now covered by different statutes. For example, the War Powers Resolution could be strengthened by making legally enforceable the "Purpose and Policy" section which permits presidential resort to "emergency use of armed forces only in the event of an attack upon the United States, or its armed forces." 236 The objection to this approach is that "it truly is impossible to predict and specify all the possible situations in which the President will need to act to protect the nation's security but will not have time to consult Congress." ${ }^{237}$ For example, commentators and executive officials cite a hypothetical future attack on Canada or Mexico, the 1962 Cuban missile crisis, and the suppression of civil insurrection abroad as instances in which unilateral executive use of force would be both warranted and beyond the executive's traditional constitutional war powers. ${ }^{238}$

The liberal response is that the avoidance of unilateral executive military adventures abroad requires that a clear line be drawn limiting executive authority: the Constitution drew that line at executive response to an attack by another nation. Emergency situations, which threaten the life of the nation and require the executive to respond so quickly as to preclude prior congressional authorization, are best addressed not by allowing broad executive discretion, even limited temporally, but by forcing the President to respond to such emergencies by openly acting unconstitutionally. The President would then immediately seek congressional and public ratification of such action.

In a related context, executive power to engage in covert paramilitary activity abroad without explicit congressional authorization should be eliminated, as recommended by the House Governmental Operations

235. Professors Francis Wormuth and Edwin Firmage have also concluded that the "solution to the problem of emergency" is:

[I]f the President believes that the necessity is sufficiently great, he should act and look to

Congress for ratification of his actions. He should not claim an emergency power to act against the law for the good of the nation, nor should he claim the exclusive right to determine what is good for the nation.

F. WORMUTH \& E. Firmage, supra note 26, at 15.

236. The only other occasions upon which the President can introduce U.S. armed forces into hostilities are pursuant to specific statutory authorization or a declaration of war. 50 U.S.C. $\S 1544(c)$ (1982). Various commentators have suggested that the Resolution would be strengthened by making Section 2(c) legally binding and enforceable. See supra note 217 . There is strong sentiment among commentators that $\$ 1544$ (c) should be expanded to include the allowance of emergency use of force to protect citizens of the United States in very narrowly defined situations, as the original Senate version of the Resolution permitted. S. 440, 93rd Cong., 1st Sess. $\S 3$ (1973). See also Durand v. Hollins, 8 Fed. Cas. 111 (S.D.N.Y. 1868) (No. 4,186) (permitting executive use of armed forces to "protect" citizens).

237. Ely, supra note 143, at 1394; see also Rostow, Great Cases Make Bad Law, supra note 25, at $842-43$ (1972) (impossible to codify all possible emergency situations).

238. Ely, supra note 143, at 1394; King \& Leavans, Curbing the Dog of War: The War Powers Resolution, 18 HARv. INT'L L.J. 55, 80-81 (1977); Note, A Defense of the War Powers Resolution, 93 YALE L.J. 1330, 1334 (1984). 
Committee in $1976^{239}$ and more recently by Congressman Fowler in 1983. ${ }^{240}$ This legislation has not been adopted, in part due to the view that the President needs flexibility to act in an emergency. The President, however, should not have the flexibility to unilaterally initiate covert warfare abroad. Open democratic debate should precede decisions to intervene militarily in a foreign country to ensure that strong national security concerns are at stake. ${ }^{241}$ To prohibit paramilitary activities abroad without a specific congressional authorization would restore the emergency/nonemergency distinction by forcing the President to act unconstitutionally if a true national emergency required such a response. Such a rule might lead a risk-averse president to forego a course of action actually in the national interest. The dangers of excess caution, however, are far outweighed by the dangers of precipitous entry into warfare abroad.

The Church Committee similarly relied on the liberal paradigm to support its proposed ban on the assassination of foreigners abroad. The Committee endorsed a proposal that would place any presidential authorization of such assassinations in conflict with the law, to ensure that the President would take such action only when required by an "indispensable necessity" to the life of the nation. ${ }^{242}$

Finally, the National Emergencies Act could be amended to limit executive emergency power to situations in which war has already been declared or the United States has been attacked, unless an emergency is specifically declared by joint resolution of Congress. Such an amendment, introduced by Congressman Drinan during the debate on the NEA, was rejected as hindering executive flexibility to act in times of crisis. ${ }^{243}$

In the context of current United States foreign policy, this traditional liberal approach of creating sharp, fixed distinctions is likely to be both utopian and dangerous. If governmental actors consistently perceive revolutionary movements and civil wars to raise grave threats to national security, the result of the traditional liberal model would be the allowance of continuous governmental lawlessness. For example, while Oliver North justified his actions by a broad reading of the constitutional powers of the

239. H.R. REP. No. 833, 94th Cong., 2d Sess. 2 (1976). The Senate Select Committee on Intelligence recommend prohibiting various classes of covert action such as "efforts to subvert democratic governments" or assassinating foreign officials. Church Comm. Report supra note 90, at 448; see also Lobel, supra note 26 (suggesting prohibiting executive-sponsored paramilitary action undertaken without congressional approval).

240. Congressional Oversight of Covert Activities: Hearings Before the House Permanent Select Comm. on Intelligence, 98th Cong., 1st Sess. 4 (1983).

241. The framers' judgment, still relevant today, was that the Constitution ought to make military intervention difficult, even if the intervention was to be undertaken by foreigners with our aid. Lobel, supra note 26; see Halperin, Lawful Wars, 72 Foreign POL'y 173 (1988).

242. See The Intelligence Community 810 (T. Fain, K. Plant \& R. Milloy eds. 1977). The Committee's proposal was not cnacted.

243. 121 Cong. Rec. 276456 (Sept. 4, 1975). 
President and a narrow reading of the Boland Amendment, he also raised the national emergency exception to the rule of law. ${ }^{244}$

The answer, however, is not to yield virtually unlimited constitutional power to the President-a position which itself undermines the rule of law-but to rethink the current search for domination leading to ever present crisis, to reject a foreign policy based upon an ever present worldwide communist threat. In that context, the liberal approach would again serve the function of providing a legal device to separate emergency power from the normal foreign affairs powers of the government.

\section{Beyond The Liberal Model of Emergency Powers}

The current crisis of liberalism reflects, in part, the transitional age in which we live-an era caught between the traditional nation-state system and the increasing interdependence of the international community. ${ }^{245}$ In a transformative era, the shortcomings of the traditional approach will often be perceived, yet alternative visions will either not be clear or appear utopian.

To the extent it is possible to look beyond the short-term solutions of the liberal model, a transformative vision must insist on two very different, but complementary changes from our present situation. The first would be the further development of the international system of governance, supplementing nation-states and simultaneously weakening the "usversus-them" perspective that characterizes the present nation state sys-

244. North testified that he had lied to Congress in order to save lives. O. NoRTH, TAKING THE STAND 256 (1988). His secretary, Fawn Hall, apparently subscribed to Jefferson's position that sometimes one must go above the written law. Similarly, it is unclear whether the FEMA plan was perceived as a constitutional suspension of rights or an extra-constitutional, emergency suspension of the Constitution itself. The key difference between the traditional, liberal-Jeffersonian approach and Oliver North's defense, lies in Jefferson's clear requirement that in taking emergency action in derogation of law, the executive must openly defend such action and seek congressional and public approval. North, in contrast, acted secretly to avoid public or congressional scrutiny. M. Briand, Civil Disobedience: The Missing Defense for Iran-Contra Activists, L.A. Daily J., June 30, 1987, at 4, col. 1. Moreover, for Jefferson and Madison such emergency action was exceptional, confined to the gravest national emergencies, while North's claim would make the exception applicable to virtually any national security crisis perceived by the executive.

Former Attorney General Meese has also recently relied on Locke's executive preogative to justify broad presidential power. Meese, supra note 135, at 226-27. Meese, unlike Jefferson, argues that "under our Constitution, the executive can exercise the power that Locke envisioned and stay within the law." Id.

245. As Richard Falk has suggested, the inability of the present political, economic, and legal orders to deal successfully with the challenges faced by an increasingly integrated world resembles the inability of feudalism and medievalism to solve the problems of Europe from the fourteenth to seventeenth centuries. Falk, Some Thoughts on the Decline of International Law $\mathcal{F}^{2}$ Future Prospects, 9 Hofstra L. Rev. 399, 410 (1980). See also International Law, A Contemporary PerspecTIvE 7 (R. Falk, F. Katochuil \& S. Mendlovitz eds. 1985) (describing this juncture in international relations as a Grotian moment).

The present inability of the old liberal paradigm to provide solutions to a wide variety of constitutional problems has led many scholars to reject the model entirely. See, e.g., LIBERALISM and ITS Critics 125-265 (M. Sandel ed. 1984) (essays criticizing liberal models); Polrtics of LAW, A ProGressive CRITIQue (D. Kairys ed. 1982); Tushnet, An Essay on Rights, 62 Tex. L. Rev. 1363 (1984). 
tem. The second change would involve reviving communalist politics, in which the citizenry, often acting through local communities, plays a more active role in determining our relations with peoples of other nations. Both changes undermine the liberal system's basis in distinct national rules: one by internationalizing government, the other by localizing it and making the citizenry into active participants in the decisionmaking process.

These changes would supplement and ultimately transform traditional separation of power restraints. The constitutional restraints on the executive are the product of a fear of unilateral decisionmaking by any one person. In an effective multinational system, unilateral United States executive power would be restrained by international political and legal processes. Moreover, active citizen and local participation in foreignpolicy making would reduce the power of the centralized government, rendering unrestrained executive adventurism less likely. The legal restraints currently provided horizontally within the national government by separation of powers would be supplemented by vertical restraints imposed by international society and popular community pressures.

In addition, these changes would undermine one important basis of the emergency/normalcy dichotomy-the fear of other peoples. Liberal society has traditionally addressed that fear by seeking to remove it physically by isolating ourselves, and constitutionally by separating emergency power from the normal constitutional order. ${ }^{246}$ Increased people-to-people relations between American communities and other societies is likely to change the perspective that views the other as the enemy, as will the development of a more multinational governmental structure. As Louis Hartz has noted, "the larger forces working toward a shattering of American provincialism" require "nothing less than a new level of consciousness, a transcending of irrational Lockianism, in which an understanding of self and an understanding of others go hand in hand."247 While tension and strains would still exist with other countries, such tensions could be resolved without resort to an "emergency" paradigm.

The resulting normative vision would probably rely more on community interaction and less on fixed rules to govern our lives. Situations would be categorized not as emergency or non-emergency, but by their particular characteristics. ${ }^{248}$ Eschewing a reliance on fixed rules to order

246. See infra notes $52-58$ and accompanying text.

247. L. HARTZ, supra note 55 , at 308 .

248. The approach outlined above shares some of the attributes of the fluid legal realist perspective on foreign affairs decisionmaking. The key differences lies in both the context of and the actors involved in such an 'interactive' approach.

In the context of current United States foreign policy, the legal realist model results in the weakening of constitutional restraints on the executive and the relative absence of effective alternative restraints. In a transformed international and domestic context, a contextual, less rule-oriented approach would rely on international governmental cooperation and popular participation in international affairs to provide a multifaceted series of restraints on "emergency" power. Moreover, a new contextual 
our lives requires decisionmaking that focuses on the particular consequences of the concrete alternative possibilities in discrete situations. ${ }^{249}$ Such a contextual approach views experience as concrete and multifaceted rather than universal and binary. ${ }^{250}$

The possibility of these transformations lies within the shadows of the present. ${ }^{251}$ While the bright hopes of a world government that accompanied the establishment of the United Nations have faded, Gorbachev's new perspectives, the increasing interdependence of the world's economies, and awareness of the vulnerability of the global environment have renewed interest in multilateral institutions and cooperative approaches. In addition, the revival of scholarly interest in citizenry participation in government ${ }^{252}$ has proceeded apace with an actual revival of citizen participation in foreign affairs issues. Localities have begun passing resolutions on foreign policy issues, adopting sister cities in other parts of the world, and actively refusing to cooperate with emergency plans proposed by such agencies as FEMA. ${ }^{253}$ Citizens across the country have engaged in acts of civil disobedience to display their disapproval of policies in Central America ${ }^{254}$ Anti-nuclear activists have also taken to the streets and jails to protest the United States' continuation of the nuclear arms race. These citizen and community movements contain two important transformative aspects. First, they do provide some concrete, democratic restraint on executive usurpation of power. Secondly, by directly interacting with people whom we have been taught to fear and distrust, these movements help

approach would have to be premised on a substantive reduction of the fear of other peoples that underlies the liberal model. The cooperation envisioned would not be merely between branches of government in order to combat foreign threats, but between communities of different nations to solve common problems.

249. Mazor, The Crisis of Liberal Legalism, 81 Yale L.J. 1032, 1052-53 (1972). See also T. May, Psychology, Knowledge, Politics: The Epistemic Grounds of Michael Foucault's Genealogy of Psychology ch. 7 (1989) (unpublished manuscript) (on file with author) (interpreting Foucault's micropolitical approach).

250. Professor Michelman argues that much of our constitutional dialogue occurs outside the formal channels of electoral and legislative politics: for example, in town meetings, voluntary organizations, and local government agencies. "Those are all arenas of potentially transformative dialogue." Michelman, Law's Republic, 97 YALE L.J. 1493, 1531 (1988). To citizen activists of the last few decades, law is not merely the positivistic command of the sovereign, but a product of the community's experiences and values that they articulate. See Cover, The Supreme Court, 1982 Term-Foreword: Nomos \& Narrative, 97 HaRv. L. Rev. 1 (1983) (law stems from community). That different vision of law as deriving from community interaction is more multidimensional and particularized than the traditional binary model of liberal thought.

251. Falk, The Grotian Quest, in International Law, A Contemporary Perspective, supra note 245 , at 36 .

252. B. Barber, Strong Democracy, Participatory Democracy for a New Age (1984); see, e.g., Michelman, supra note 250; Brest, Constitutional Citizenship, 34 Clev. ST. L. REv. 175 (1986); Brest, Further Beyond the Republican Revival: Toward Radical Republicanism, 97 YALE L.J. 1623 (1988).

253. Shuman, Dateline Main Street: Local Foreign Policies, 65 ForeIGN PoL'y 154 (Winter 1987).

254. See Falk, Introduction, in Boyle, Defending Civil Resistance Under InTERnational LAW (1987). 
break down the fears upon which the emergency/normalcy dichotomy is premised.

While these efforts are on the margin of current mainstream thought on foreign affairs, one commentator argues that the "shift from pre- to posttransformation practice is more like a movement from margin to center-a shift of attention-than it is like a total replacement of one 'world' by another." ${ }^{255}$ Such a perspective describes the shift from the liberal view to the relativist view in the twentieth century; possibly the current citizen's movement will move from the margin to the center in the twenty-first century.

The struggle to revive the dichotomies of liberal thought is therefore contradictory. On the one hand, the separation of experience into opposites allows for the development of neutral rules and political democracy. Unlike the situation existing in the Middle Ages, or under fascist government, liberalism's separation of spheres allows for the relegation of totalitarian, arbitrary government to discrete crisis periods. The weakening of these dichotomies raises a grave danger of authoritarian rule in the conduct of foreign affairs. For any restoration of the dichotomies to attempt to remedy this situation, the sense of continual, permanent crisis must be eliminated.

However, the changing global and domestic context presents a possibility for transforming the liberal model by providing international and communalist restraints on governmental power. Such a solution would attempt to overcome the fears that lead to the necessity for emergency power, instead of merely limiting emergency power by means of legal rules. We must seek to revive the dichotomies of liberal thought, yet recognize that the restriction of emergency powers ultimately requires the abandonment of the dualistic model. 
